Article

\title{
Organizational Culture and Subcultures in the Spanish Nuclear Industry
}

\author{
Eulàlia Badia ${ }^{1, *}$, Joaquín Navajas ${ }^{1}$ and Josep-Maria Losilla ${ }^{2}$ (]) \\ 1 Sociotechnical Research Centre of the Energy, Environment and Technology Research Centre (CIEMAT), \\ Mòdul de Recerca A, Plaça del Coneixement s/n, Campus de la UAB, \\ 08193 Bellaterra (Cerdanyola del Vallès), Barcelona, Spain; joaquin.navajas@ciemat.es \\ 2 Department of Psychobiology and Methodology of Health Science, Area of Behavioral Science Methodology, \\ Carrer de la Fortuna, Edifici B, Despatx B5-065, Campus de la UAB, \\ 08193 Bellaterra (Cerdanyola del Vallès), Barcelona, Spain; JosepMaria.Losilla@uab.cat \\ * Correspondence: eulalia.badia@ciemat.es; Tel.: +34-935-868-788
}

Received: 28 April 2020; Accepted: 14 May 2020; Published: 17 May 2020

check for updates

Featured Application: The description of organizational culture within the nuclear industry, as well as the identification of specific subcultures, favor the adaption of organizational intervention and improvement programs, thus benefiting safety culture.

\begin{abstract}
Organizational culture determines the norms, values and behaviors of an organization, playing a key role in the safety of high-reliability organizations (HRO). Previous research has shown that differentiated subcultures can coexist within organizations, sharing some norms and values but not necessary everything From this perspective, this study was aimed at (1) describing the organizational culture of the Spanish nuclear industry and (2) determining the potential presence of organizational subcultures. To do that, a statistical analysis of organizational culture surveys (Organizational Culture Inventory ${ }^{\circledR}, \mathrm{N}=5825$ ) handed over to all organizations within the Spanish nuclear industry, was carried out. Results allow us to accurately characterize the industry's organizational culture, which is made up of predominant "Constructive"-style behaviors together with "Defensive" normative patterns of the "Conventional", "Dependent" and "Perfectionistic" styles. Indications about the existence of various subcultures associated to the nuclear organization type, the sociodemographic aspect and the organizational structure component were also found. Certain safety implications potentially linked to the existence of subcultures and to the industry's organizational culture are discussed.
\end{abstract}

Keywords: organizational culture; organizational subcultures; safety culture; nuclear industry; organizational culture inventory; organizational components of Mintzberg

\section{Introduction}

This paper aims to describe the organizational culture of the Spanish nuclear industry and to identify the existence or nonexistence of different organizational subcultures. To do that, three theoretical elements were taken as the reference framework for this research: (a) a concept of culture as a decisive factor determining the behavior of individuals within the organization; (b) the acknowledgment that multiple subcultures might exist within the same organization and (c) the need to consider organizational structure as an element potentially contributing to the creation of subcultures. 


\subsection{Organizational Culture}

Culture studies have become a crucial part of the behavioral landscape of the organizational sciences [1]. It is worth mentioning the interdisciplinarity of the term "culture" and the multiplicity of approaches. In that sense, anthropology has focused mainly on the knowledge of collective meanings, within which culture would be comprised of "the body of norms regulating a number of social groups" [2] (p. 56). Sociology has highlighted the nature of social interaction which eventually causes groups of individuals to create a particular different collectivity [3]. As for psychology, the term was linked to external adaption and internal integration [4], focusing on its influence on behavior and on interpreting how others behave [5].

An organization's culture could be conceived as a set of common norms, values and world visions that develop within the organization when its members interact with each other and their context [6]. Organizational culture restricts the possibilities of action, entrenched in "the way we do things around here" [7] (p. 4). In fact, the definitions of culture are multiple and vary in content, scope of aspects addressed and depth of their analyses [8]. One of the most relevant differences is that culture could focus on both observable aspects and others of a deeper nature with no evident manifestations. Within organizational sciences, it is possible to differentiate two types of studies [9]: those focused on identifying basic assumptions (the way people think) and those focused on consequences (the way people behave). Hofstede [10] believes that shared perceptions on daily practices should be considered as an organization's core culture.

In organizational literature, it is recognized that the culture of an organization may imply dysfunctional outcomes that lead to low efficiency and performance levels, even when personnel are committed and competent [11]. Some types of organizational culture are associated to positive outcomes, either in terms of organizational effectiveness or of individual performance [7,12]. Culture determines the quality of working life and professional performance [13,14], impacting organizational change and transformation [15].

On the other hand, the analyses of catastrophic accidents such as Fukushima or Chernobyl have favored the acknowledgment of how organizational aspects affect safety [16-18]. Therefore, this means the safety of an organization could be improved by intervention of its organizational culture [19].

\subsection{Organizational Subcultures}

The second aspect addressed by our study is related to the term "subculture", which has sparked major scientific debate within organizational literature. Both the uniformity of organizational culture and the desirability of such uniformity due to its impact on efficiency, have been contested.

Generally speaking, it seems commonly accepted that there are only a few organizations with a homogeneous, compact culture [20,21]. According to Reason [22], culture is not a single construct, but the combination of multiple organizational elements continuously interacting, such as problem reporting and organizational learning, amongst others. As for Schein [20], organizational subcultures may share some values but not others; in fact, they could completely differ in terms of basic organizational values.

Martin [23] identifies three perspectives in the study of organizational culture: (a) Studies postulating a uniform, consistent organizational culture throughout the organization (integration). These are the most common studies. (b) Studies which identify differentiated cultural manifestations within the organization (differentiation). (c) Studies considering that it is not possible to reach a culture agreement due to the existence of multiple and at times opposed visions (fragmentation). From Martin's differentiation perspective, the working environment can be conceived as a combination of different groups—subcultures—with specific characteristics $[8,9,24,25]$.

Many studies have tried to identify which group features or factors determine the setting of possible subcultures. Some of the aspects considered relate to structure (departments, work groups, place in the organization), task features, occupational levels, work experience and affiliations [20,21,26,27]. 
Considering a broader perspective, Hofstede [10] conceptualizes the existence of different culture levels based on aspects relating to nation, region, ethnicity, religion and gender.

Some studies link the existence of subcultures to aspects relating to traits either professional [28-30] or occupational [31]. According to Koene et al. [32], subcultures are associated with differentiated tasks and to a lack of contact and interdependence. Similarly, Black [33] thinks that training-related occupational subcultures may exist, as well as departmental subcultures.

Likewise, when task characteristics (production group) and organizational seniority are considered, differences in occupational satisfaction and motivational aspects were identified in specific groups within the industry. For instance, the longer workers are in the organization, the lower the motivation [34]. Studies of subcultures in healthcare organizations have found satisfaction differences related to work-related autonomy and wages [35]. Rose [36] adds that the level of satisfaction with dominant culture values may increase the likelihood of individuals joining specific subcultures.

Copuš et al. [34] point out that it can be generally said that organizations of the same type include similar subcultures. Within the area of healthcare, it is possible to identify a subculture of doctors differentiated from the subculture of nurses, whereas in other industries, the subculture of production personnel can be found. Similarly, Park and Jung [37] point out that operators from different Korean nuclear power plants share a similar cultural profile, different from the rest of the organization.

In short, previous research shows that organizational subcultures can be created as a result of multiple and differentiated elements.

\subsection{Subcultures and Safety}

A relevant aspect of our study is related to the existence of subcultures and their potential impact on safety. In fact, the interest in subcultures within high-risk organizations is determined by their potential influence on safety. This leads to the following critical question: How does the existence of different cultural groups within high-reliability organizations impact safety? In other words, can the existence of different subcultures within an organization be a risk factor for safety?

According to the International Atomic Energy Agency (IAEA) [38] (p. 7), the existence of subcultures is not an element that has a positive or negative impact per se:

'Is the existence of subcultures likely to be harmful? One viewpoint is that, unless the different subcultures all contain something that results in a common sense of purpose, different priorities and agendas can arise and this can create serious problems. The counterargument is that different subcultures give different perspectives, and this is advantageous.'

The literature of organizations does not seem to provide a clear answer either. Some theoretical approaches to the study of complex, high-risk organizations acknowledge subcultures and their potential strength for safety as a key element. From the perspective of the man-made disaster theory [39], accidents are caused by a lack of information flow. This perspective considers that within an organization, there are warning signs that, if detected, could prevent accidents. Signs which are most likely known by an organizational subgroup. Therefore, the existence of subcultures is not necessarily negative; in fact, acknowledging and managing them could contribute to preventing 'safety blind spots' [40]. Boisnier and Chatman [41] also consider that subcultures can develop within a strong, integrated culture without weakening it and with the aim of strengthening the organization's flexibility to change and adapt to external contingencies. In that sense, organizations with increased cultural variety are better prepared to respond to complex environments. According to Wahlström [42], cultural differences should be considered key factors of safe evolutions in nuclear facilities, meaning research should focus on how safety is built as a result of cultural interactions.

On the contrary, other authors defend the need of cultural integration as a way to ensure organizational reliability and safety. Rollenhagen et al. [30] consider that the existence of differentiated professional subcultures hampers cooperation and negatively affects safety. In their study, they analyze differences between three groups (maintenance, operations and engineering) of three Swedish 
nuclear power plants, focusing on key safety climate aspects such as safety management, occupational safety and resources. Similarly, another study in the Norwegian oil and gas industries reveals the existence of different ways to interpret safety rules. Such interpretation varies depending on whether personnel belong to management, engineering or operations, thus impacting differentiated regulatory compliance [43].

\subsection{Organizational and Cultural Structure}

Thirdly, this study believes it is relevant to analyze the relationship between organizational structure and organizational culture. It is important to mention Mintzberg's paramount contribution, in which he conceived organizational structure as 'the total of the ways in which labor is divided into distinct tasks and then its coordination achieved among those tasks' [44] (p. 100).

According to Mintzberg [45] (p. 99), there are six clearly differentiated organizational components within organizations, as shown in Figure 1.

\section{Six Basic Parts of the Organization}

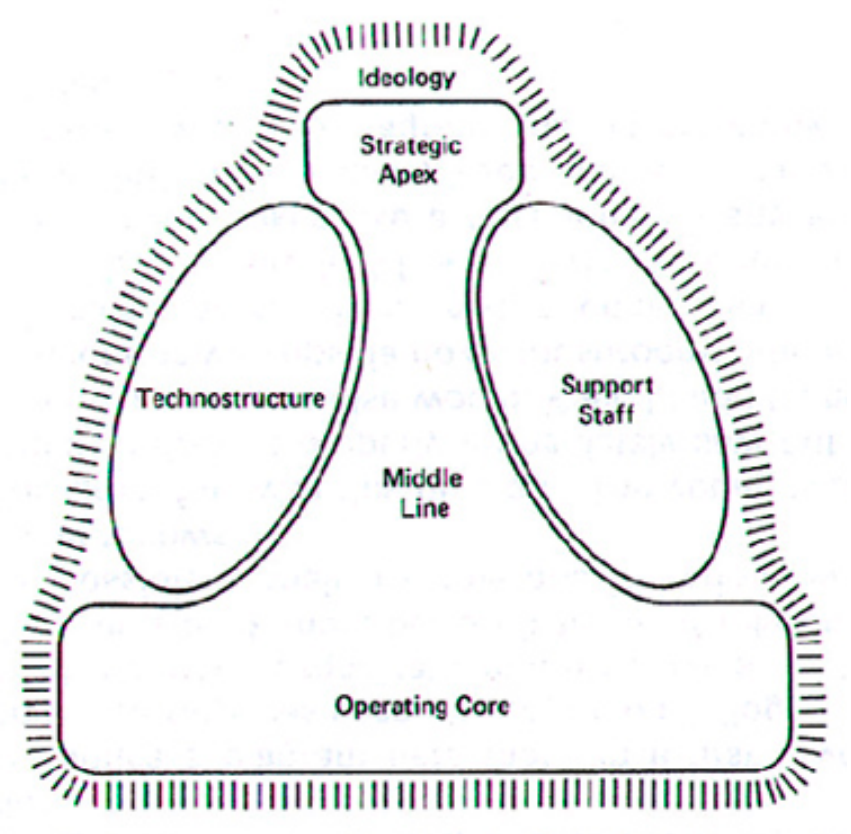

Figure 1. Mintzberg's organizational components.

Figure 1 shows that people whose work is directly related to products and services, named "operating core", are at the base of the organization. In the upper part we can find the "strategic apex", responsible for overviewing the entire organization, ensuring its mission is met and owners' needs are satisfied. Between the "strategic apex" and "operating core" sits the "middle line", a chain of managers with formal authority in productive processes. There are two additional components outside the line of authority. The "technostructure", focused on the design and performance of process standardization, and the "support staff", providing specialized support in administrative or financial aspects, amongst others.

It is important to mention that Mintzberg introduces a sixth element known as "ideology", which provides coherence and uniformity to all other organizational components. Ideology, an element considered by Mintzberg as somewhat equivalent to the concept of culture, would include organizational aspects such as traditions and beliefs, thus adding uniqueness to the organization compared to others. Other ideology-derived aspects are 'the personal relationship between the individual and the organization or the collective nature of responsibility and choice' [45] (p. 233). It is important to emphasize that according to Mintzberg, ideology is clearly associated to the organization 
as a whole, without apparent differences amongst organizational components. Thus, his concept of ideology could be considered equivalent to an organizational unitary culture.

In addition to defining the parts structuring organizations, Mintzberg develops a theoretical model with seven typical organizational configurations (entrepreneurial, machine, professional, diversified, innovative, missionary and political). His analysis of organizational structure and typology has influenced the analysis of high-risk organizations. Haber et al. [46] pointed out that nuclear power plants can be described under the machine bureaucracy model, with some structural differences within the operating core. Mintzberg would also support this approach to nuclear organizations. According to him, 'an important condition that drives this organization to a machine bureaucracy is its special need for safety' [47] (p. 332). This would mean that procedures are formalized extensively to ensure that they are carried out and result in safe operation.

\subsection{Theoretical Foundation of Our Approach}

As a summary, the three main theoretical aspects taken as reference framework for the development of this study, are presented below.

Firstly, organizational culture is conceived as a factor determining human behavior within organizations. Furthermore, as revealed in the analysis of catastrophic events in high-risk industries, it is necessary to consider that organizational culture has an impact on the management of safety.

Secondly, this study takes the differentiation perspective of Martin as reference framework, thus considering that the working environment is comprised of groups with differentiated subcultures, in line with the views of Guldenmund [48] (p. 26):

'Cultures are neither homogeneous not fully integrated. On the one hand, because disagreement and even conflict will always arise. On the other hand, because people within a culture adopt its core with mixed intensity.'

At this point, it is important to clarify that we agree with the following definition of organizational subculture [49] (p. 38):

'A subset of an organization's members who interact regularly with one another, identify themselves as a distinct group within the organization, share a set of problems commonly defined to be the problems of all, and routinely take action on the basis of collective understandings unique to the group.'

From this differentiation perspective, we think it is relevant to assess the complementarity of organizational subcultures to prevent the existence of "blind safety spots" [40].

Thirdly and last, this study embraces the approach of Mintzberg [45] on the relevance of organizational structure and its organizational components, which in our opinion, could be contributors to the creation of subcultures.

Based on these theoretical perspectives, our research is focused on the following:

1. Describing the organizational culture of the Spanish nuclear industry.

2. Identifying features of different subcultures within the Spanish nuclear industry. To do so, the influence of some demographic variables on organizational culture is analyzed. The following variables have been studied:

- Sector (working at nuclear power plants or at nuclear public companies);

- Location (working at the facility or at the headquarters);

- Contractual relationships (own staff or contractors);

- Organizational components identified by Mintzberg [45] (strategic apex, middle line, operating core, technostructure and support staff). 


\section{Materials and Method}

Within the context of the Spanish nuclear industry, the relationship between nuclear facility safety and organizational aspects has been prioritized within the field of research. In 1999, a collaboration agreement was signed between the Spanish nuclear regulator (CSN), Spain's Public Research Agency for Energy, Technology and Environment (CIEMAT) and the Spanish Association of Utilities (UNESA). Such agreement led to the development of a research program and to the establishment of independent safety culture evaluations carried out in nuclear organizations. It was agreed to use the evaluation methodology applied in the Canadian nuclear industry [50]. Such methodology has been used continuously in all Spanish nuclear facilities since the year 2000.

\subsection{Sample Characteristics}

This study takes as object of analysis the quantitative data obtained via external organizational culture evaluation surveys collected between the years 2007 and 2019. The sample consists of 5825 workers from all Spanish nuclear power plants (including Garoña NPP, now under decommissioning) and the public nuclear industry companies: management of radwaste and dismantling processes (ENRESA), manufacture of nuclear fuel (ENUSA) and manufacture of nuclear equipment components (ENSA). The study sample is composed of data from the latest safety culture assessment conducted in each organization. Data from more than one culture assessment per organization is not included. The different size of the facilities (one or two reactors) implies that some are represented by more subjects. As shown in Table 1, a total of seven organizations are analyzed, four of them are nuclear power plants (4618 individuals) and three are public companies within the nuclear industry (1207 individuals). A total of 31 individuals were removed from the sample population as they did not respond to some scales. This led to a final sample comprised of 5794 workers. The sample includes workers from all organizational components as identified by Mintzberg. Due to confidentiality reasons, the names of these companies are not disclosed, and they will be referred to as nuclear power plant (NPP) \# or nuclear public company (NPC) \#.

Table 1. Study sample and descriptives.

\begin{tabular}{cccc}
\hline Variable & Sample N & $\begin{array}{c}\text { Total N } \\
\text { (\%) }\end{array}$ \\
\hline Organization & Nuclear Power Plant (NPP) 1 & $292(5.01 \%)$ & \\
& Nuclear Power Plant 2 & $533(9.15 \%)$ & $4618(79.28 \%)$ \\
& Nuclear Power Plant 3 & $1975(33.91 \%)$ & \\
& Nuclear Power Plant 4 & $1818(31.21 \%)$ & \\
& Nuclear Public (NPC) Company 1 & $444(7.62 \%)$ & $1207(20.72 \%)$ \\
& Nuclear Public Company 2 & $437(7.50 \%)$ & \\
& Nuclear Public Company 3 & $326(5.60 \%)$ & $5825(100 \%)$ \\
Location & Total Sample & $4530(84.53 \%)$ & $5359(100 \%)$ \\
& Facility & $829(15.47 \%)$ & \\
Contract & Headquarters & $3031(55.86 \%)$ & $5426(100 \%)$ \\
& Own Staff & $2395(44.14 \%)$ & \\
Mintzberg (NPP1) & $23(3.54 \%)$ & \\
& Contractors & $66(10.15 \%)$ & \multirow{2}{*}{$650(100 \%)$} \\
& Strategic Apex & $219(33.69 \%)$ \\
& Middle Line & $126(19.38 \%)$ & \\
& Operating Core & $216(33.23 \%)$ & \\
& Technostructure & & \\
& Support Staff & & \\
& &
\end{tabular}

\subsection{Measurement Instrument}

The survey known as OCI (Organizational Culture Inventory ${ }^{\circledR}$, copyrighted by the company Human Synergistics) [51] was used in all external evaluations and administered by members of the independent evaluating team. 
The OCI is an instrument with high internal scale consistency, as well as discriminant and convergent validity [52]. The OCI's validity and reliability have been widely proven [53-55]. It is also one of the most cited and used surveys in a large variety of fields [56].

The OCI includes 120 items assessed on a Likert scale from 1 to 5 . Items are structured in 12 styles or behavioral norms, which are in turn grouped in three types of culture [57,58]. Low scores point to norms with a lower expectation within the organization. The three types of culture established by the OCI are as follows:

- Constructive Culture: Workers are encouraged to cooperate, reaching high levels of motivation, satisfaction, teamwork and service quality.

- Passive/Defensive Culture: Organization members are expected to please individuals in positions of authority, and they wait for others to act first.

- Aggressive/Defensive Culture: Organization members are expected to oppose new ideas, to compete amongst them and to seem competent and independent.

Table 2 includes the OCI styles description (reproduced by permission of Human Synergistics).

Table 2. Descriptions of the twelve styles measured by the Organizational Culture Inventory ${ }^{\circledR}\left(\mathrm{OCI}^{\circledR}\right)$ (and sample items) *.

Constructive Norms [Cultural Styles Promoting Satisfaction Behaviors]

Achievement: An Achievement culture characterizes organizations that do things well and value members who set and accomplish their own goals. Members are expected to set challenging but realistic goals, establish plans to reach these goals, and pursue them with enthusiasm. (Pursue a standard of excellence; Openly show enthusiasm)

Self-Actualizing: A Self-Actualizing culture characterizes organizations that value creativity, quality over quantity, and both task accomplishment and individual growth. Members are encouraged to gain enjoyment from their work, develop themselves, and take on new and interesting activities. (Think in unique and independent ways; Do even simple tasks well)

Humanistic/Encouraging: A Humanistic-Encouraging culture characterizes organizations that are managed in a participative and person-centered way. Members are expected to be supportive, constructive, and open to influence in their dealings with one another. (Help others to grow and develop; Take time with people)

Affiliative: An Affiliative culture characterizes organizations that place a high priority on constructive interpersonal relationships.

Members are expected to be friendly, open, and sensitive to the satisfaction of their work group. (Deal with others in a friendly, pleasant way; share feelings and thoughts)

Passive/Defensive Norms [Cultural Styles Promoting People/Security Behaviors]

Approval: An Approval culture describes organizations in which conflicts are avoided and interpersonal relationships are pleasant-at least superficially. Members feel that they should agree with, gain the approval of, and be liked by others. ("Go along" with others; Be liked by everyone)

Conventional: A Conventional culture is descriptive of organizations that are conservative, traditional, and bureaucratically controlled. Members are expected to conform, follow the rules, and make a good impression. (Always follow policies and practices; Fit into the "mold")

Dependent: A Dependent culture is descriptive of organizations that are hierarchically controlled and do not empower their members. Centralized decision making in such organizations leads members to do only what they are told and to clear all decisions with superiors. (Please those in positions of authority; Do what is expected)

Avoidance: An Avoidance culture characterizes organizations that fail to reward success but nevertheless punish mistakes. This negative reward system leads members to shift responsibilities to others and avoid any possibility of being blamed for a mistake. (Wait for others to act first; Take few chances)

\section{Aggressive/Defensive Norms [Cultural Styles Promoting Task/Security Behaviors]}

Oppositional: An Oppositional culture describes organizations in which confrontation and negativism are rewarded. Members gain status and influence by being critical and thus are reinforced to oppose the ideas of others. (Point out flaws; Be hard to impress) Power: A Power culture is descriptive of nonparticipative organizations structured on the basis of the authority inherent in members' positions. Members believe they will be rewarded for taking charge, controlling subordinates and, at the same time, being responsive to the demands of superiors. (Build up one's power base; Demand loyalty)

Competitive: A Competitive culture is one in which winning is valued and members are rewarded for outperforming one another. Members operate in a "win-lose" framework and believe they must work against (rather than with) their peers to be noticed. (Turn the job into a contest; Never appear to lose)

Perfectionistic: A Perfectionistic culture characterizes organizations in which perfectionism, persistence, and hard work are valued.

Members feel they must avoid any mistakes, keep track of everything, and work long hours to attain narrowly defined objectives. (Do things perfectly; Keep on top of everything)

* Note: Research and development b: Robert A. Cooke, Ph.D. Style names, descriptions and items are copyrighted

(C) and used with permission. From Organizational Culture Inventory by [51] Robert A. Cooke and J. Clayton Lafferty, 1987, Plymouth, MI: Human Synergistics International. Copyright ${ }^{\circledR 2020}, 2020$ by Human Synergistics, Inc. Reproduced with permission. The OCI style descriptions and items may not be reproduced without the expressed and written permission from Human Synergistics. 


\subsection{Data Analysis}

All data analyses were conducted using IBM SPSS Statistics v22.0 [59]. The distributions of scores, skewness and kurtosis suggested data were normally distributed. Cronbach's alpha $(\alpha)$ internal consistency reliability [60] was calculated for the twelve styles of the OCI, considering acceptable values of $\alpha$ ranging from 0.7 [61]. Construct validity was examined using principal component factor analysis with varimax rotation [62]. The overall reliability of the factor solution was also tested using Cronbach's alpha.

Comparative analyses between groups (Table 3) were carried out by calculating the mean differences obtained by groups in the three organizational cultures, and on the twelve OCI styles, effect sizes were computed as Cohen's $\delta$, considering effect sizes as small $(\delta \geq 0.2)$, medium $(\delta \geq 0.5)$ or large $(\delta \geq 0.8)[63]$ (Cohen, 1988).

Table 3. Variables used in the comparative analyses.

\begin{tabular}{ccc}
\hline \multicolumn{2}{c}{ Studied Variables } & Definition \\
\hline Sector & Type of nuclear sector organization & $\begin{array}{c}\text { Nuclear Power Plants/Nuclear Public } \\
\text { Companies (companies specializing in } \\
\text { radwaste and dismantling processes, fuel } \\
\text { manufacturing and nuclear component } \\
\text { manufacturing) }\end{array}$ \\
Location & Personal workplace. & Facility/Headquarters \\
Contractual relationship & Contractual situation of workforce & Own personnel/Contractor \\
Mintzberg Component & $\begin{array}{c}\text { Organizational component in which } \\
\text { personnel are integrated according } \\
\text { to Mintzberg's classification (1989) }\end{array}$ & $\begin{array}{c}\text { Strategic Apex/Middle Line/Operating } \\
\text { Core/Technostructure/Support Staff }\end{array}$ \\
\hline
\end{tabular}

Finally, a repeated-measures mixed model analysis of variance (ANOVA) was adjusted to analyze the organizational culture according to the Mintzberg organizational classification. The between-group variable was Mintzberg's level (with five groups), and the within-group variable was organizational culture (with three measures). Bonferroni-corrected $p$-values were calculated for between-group post hoc comparisons. Tests were considered significant at $p<0.05$.

\section{Results}

\subsection{Reliabilities, Factorial Components and Global Descriptives of the OCI}

The reliability analysis provides internal consistency values that are high or very high in most scales and in the three OCI cultures. The "Dependent" $(\alpha=0.64)$ and "Oppositional" $(\alpha=0.48)$ styles provide the lowest Cronbach's $\alpha$ results.

A three-factor solution resulted from exploratory factor analysis of the OCI data. All three factors are comparable to those found in previous research [11,64], except for the styles "Avoidance" and "Perfectionistic", with factorial loading values within the "Aggressive/Defensive" and "Passive/Defensive" cultures, respectively. To ensure a more accurate comparison between our results and those of previous studies, and considering the high internal consistency in the three culture types, analyses within our study maintain the definitions for the three styles proposed by OCI authors, complementing them with comparative analyses and profiles of each individual style.

Table 4 shows results obtained from the reliability analysis, factorial analysis, as well as from descriptive OCI information. 
Table 4. Reliability, principal factor component analysis and descriptive statistics of the OCI styles.

\begin{tabular}{cccccccc}
\hline & \multicolumn{7}{c}{ Component } \\
\cline { 2 - 8 } OCI Styles & Constructive & $\begin{array}{c}\text { Passive } \\
\text { /Defensive }\end{array}$ & $\begin{array}{c}\text { Aggressive } \\
\text { /Defensive }\end{array}$ & $\begin{array}{c}\text { Cronbach's } \\
\boldsymbol{\alpha}\end{array}$ & $\mathbf{M}$ & SD & N \\
\hline Humanistic- & 0.91 & -0.03 & -0.13 & 0.93 & 3.55 & 0.87 & 5782 \\
Encouraging & 0.90 & 0.06 & -0.20 & 0.94 & 3.62 & 0.90 & 5790 \\
Affiliative & 0.87 & 0.12 & 0.10 & 0.76 & 3.37 & 0.63 & 5781 \\
Achievement & 0.90 & -0.03 & -0.02 & 0.83 & 3.35 & 0.72 & 5779 \\
Self-Actualizing & 0.07 & 0.61 & 0.42 & 0.76 & 2.82 & 0.63 & 5782 \\
Approval & -0.17 & 0.88 & 0.06 & 0.78 & 3.30 & 0.66 & 5779 \\
Conventional & 0.05 & 0.85 & 0.14 & 0.64 & 3.26 & 0.56 & 5784 \\
Dependent & -0.53 & 0.29 & 0.61 & 0.83 & 2.30 & 0.75 & 5779 \\
Avoidance & 0.26 & 0.08 & 0.81 & 0.48 & 2.77 & 0.46 & 5781 \\
Oppositional & -0.21 & 0.40 & 0.69 & 0.91 & 2.62 & 0.65 & 5790 \\
Power & -0.35 & 0.24 & 0.78 & 0.91 & 2.15 & 0.87 & 5782 \\
Competitive & 0.12 & 0.69 & 0.25 & 0.73 & 3.11 & 0.61 & 5790 \\
Perfectionistic & 0.96 & 0.89 & 0.89 & & & & \\
\hline Cronbach's $\alpha$ & 3.47 & 2.92 & 2.66 & & & & \\
M & 0.71 & 0.50 & 0.50 & & & & \\
SD & 5794 & 5794 & 5794 & & & & \\
N & &
\end{tabular}

* Note: Mean = M; Standard Deviation = SD; Sample = N. Constructive mean (Humanistic-Encouraging, Affiliative, Achievement, Self-Actualizing); Passive/Defensive mean (Approval, Conventional, Dependent, Avoidance) and Aggressive/Defensive mean (Oppositional, Power, Competitive, Perfectionistic).

Analyses show that the "Constructive" cluster is the one that best defines the organizational culture of the Spanish nuclear industry, with an average score of 3.47, followed by the "Passive/Defensive" cluster with a 2.92 average. The cluster with the lowest score is "Aggressive/Defensive", with an average score of 2.66 (Figure 2). In terms of styles (Figure 3), the highest survey score was reached in the "Affiliative" (3.62) style of the "Constructive" cluster, whereas the lowest score was in the" Competitive" (2.15) style of the "Aggressive/Defensive" cluster.

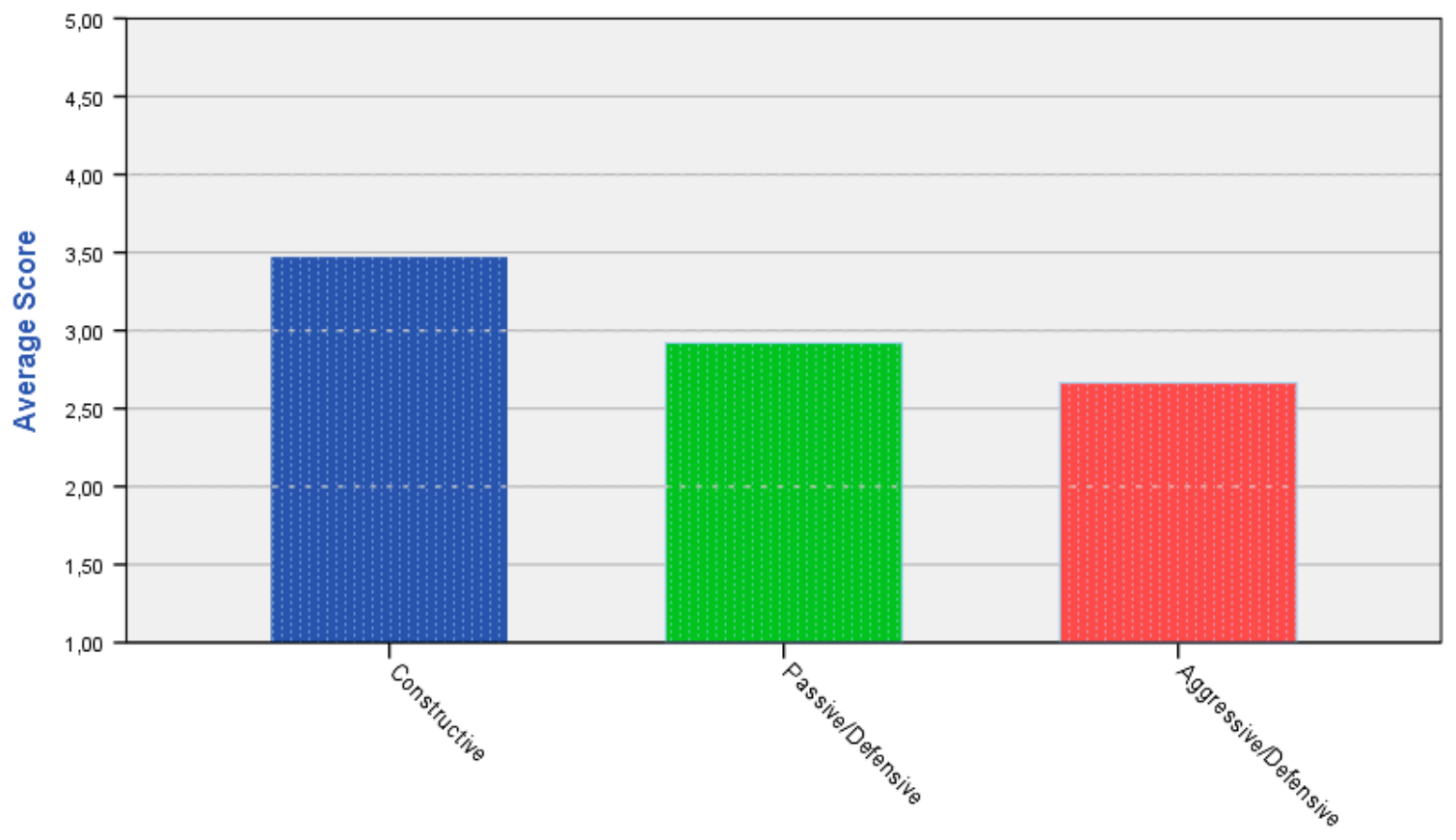

Organizational Cultures

Figure 2. OCI Organizational culture averages. 


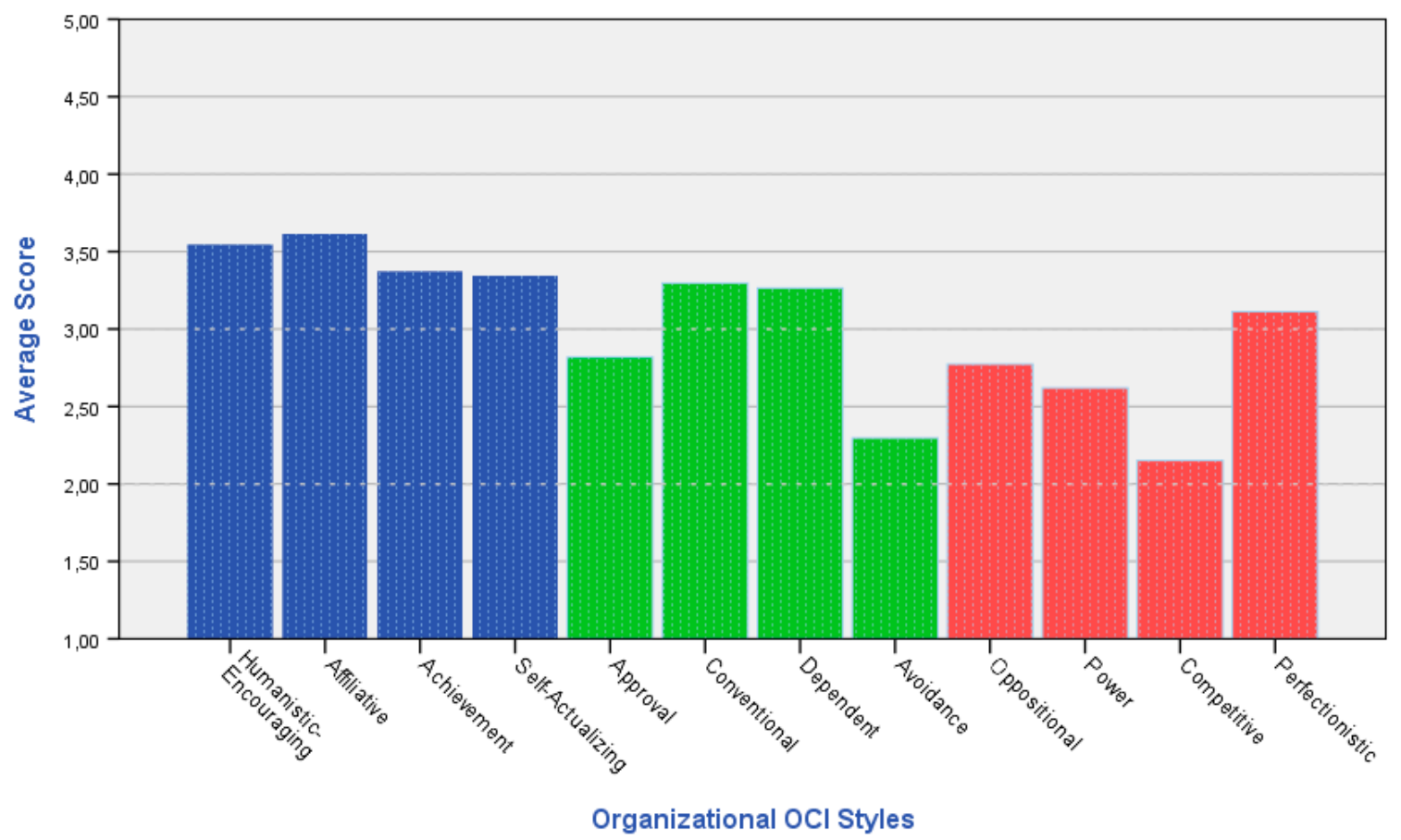

Figure 3. OCI Styles averages.

\subsection{Cultural Differences by Demographic Variables}

\subsubsection{Differences by Type of Organization}

The comparative analysis by type of organization shows relevant differences between nuclear power plants (NPP) and nuclear public companies (NPC) (Table 5; Figure 4). NPP have higher average scores (M) in the" Constructive" cluster (NPP M $=3.55$; NPC M $=3.18 ; \delta=0.54$ ) whereas NPC scores higher in the "Passive/Defensive cluster" (NPP M = 2.89; NPC M = 3.04; $\delta=-0.30$ ).

Table 5. Descriptive statistics of the OCI organizational cultures and styles for the nuclear industry and differences between nuclear power plants (NPP) and nuclear public companies (NPC).

\begin{tabular}{|c|c|c|c|c|c|c|c|}
\hline \multirow[b]{2}{*}{ OCI Styles } & \multicolumn{2}{|c|}{ Nuclear Industry } & \multicolumn{2}{|c|}{ NPP } & \multicolumn{2}{|c|}{ NPC } & \multirow{2}{*}{$\frac{\text { NPP/NPC }}{\text { Cohen's } \delta}$} \\
\hline & $\mathbf{M}$ & SD & $\mathbf{M}$ & SD & $\mathbf{M}$ & SD & \\
\hline Humanistic-Encouraging & 3.55 & 0.87 & 3.65 & 0.85 & 3.16 & 0.86 & 0.57 \\
\hline Affiliative & 3.62 & 0.90 & 3.71 & 0.89 & 3.26 & 0.84 & 0.52 \\
\hline Achievement & 3.37 & 0.63 & 3.43 & 0.60 & 3.15 & 0.67 & 0.46 \\
\hline Self-Actualizing & 3.35 & 0.72 & 3.40 & 0.70 & 3.14 & 0.74 & 0.38 \\
\hline Approval & 2.82 & 0.63 & 2.80 & 0.65 & 2.91 & 0.57 & -0.18 \\
\hline Conventional & 3.30 & 0.66 & 3.27 & 0.67 & 3.41 & 0.62 & -0.22 \\
\hline Dependent & 3.26 & 0.56 & 3.24 & 0.56 & 3.35 & 0.53 & -0.19 \\
\hline Avoidance & 2.30 & 0.75 & 2.25 & 0.74 & 2.48 & 0.73 & -0.32 \\
\hline Oppositional & 2.77 & 0.46 & 2.79 & 0.46 & 2.69 & 0.46 & 0.22 \\
\hline Power & 2.62 & 0.65 & 2.60 & 0.65 & 2.70 & 0.64 & -0.15 \\
\hline Competitive & 2.15 & 0.87 & 2.10 & 0.89 & 2.36 & 0.79 & -0.31 \\
\hline Perfectionistic & 3.11 & 0.61 & 3.11 & 0.61 & 3.14 & 0.60 & -0.05 \\
\hline Constructive & 3.47 & 0.71 & 3.55 & 0.69 & 3.18 & 0.71 & 0.54 \\
\hline Passive/Defensive & 2.92 & 0.50 & 2.89 & 0.51 & 3.04 & 0.46 & -0.30 \\
\hline Aggressive/Defensive & 2.66 & 0.50 & 2.65 & 0.50 & 2.72 & 0.47 & -0.15 \\
\hline
\end{tabular}

${ }^{*}$ Note: Mean $=\mathrm{M}$; Standard Deviation $=$ SD. 


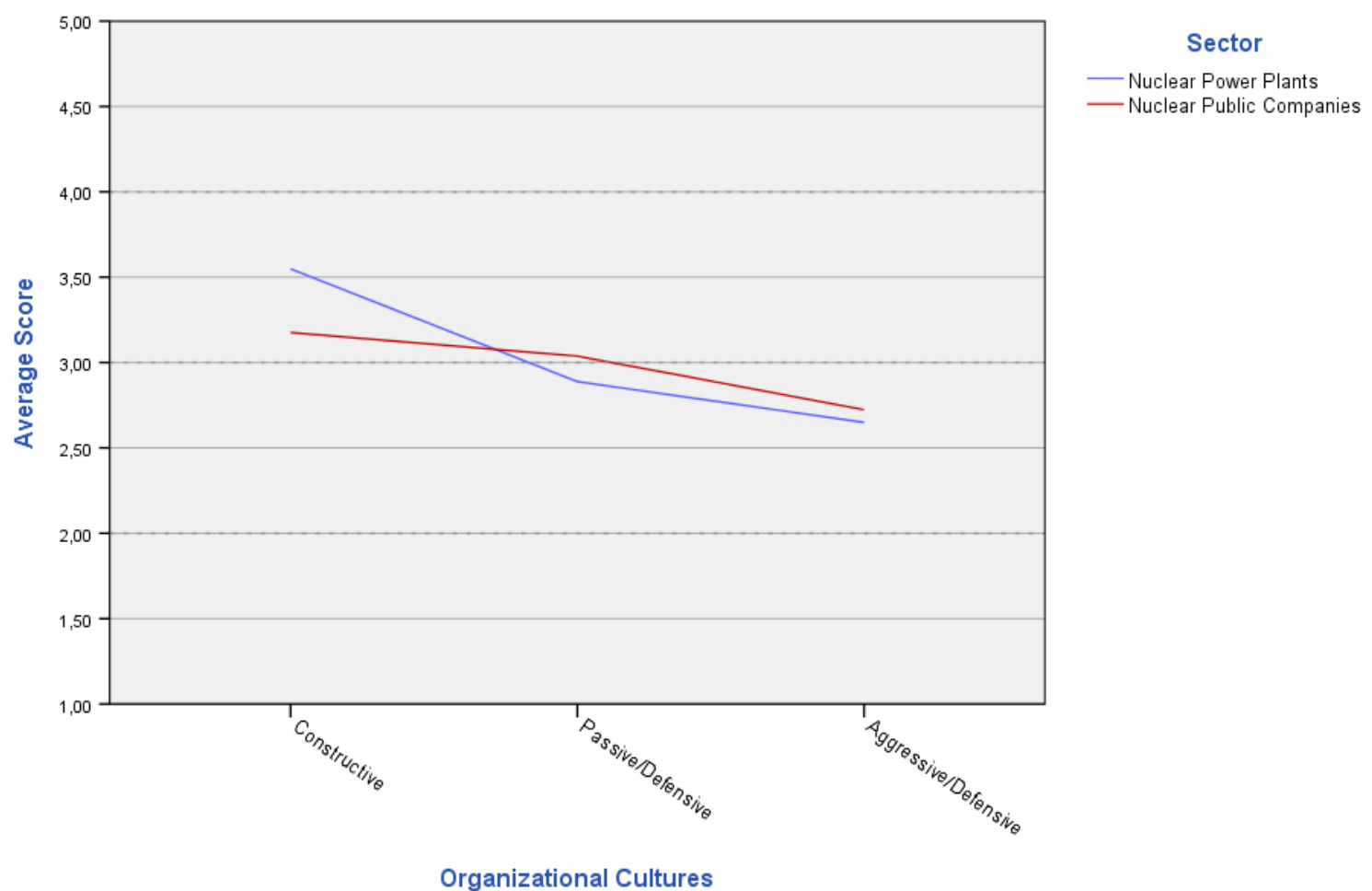

Figure 4. OCI organizational cultures averages by nuclear sector.

Within the "Constructive" cluster, it is worth mentioning the differences in the "Humanistic-Encouraging" (NPP M $=3.65 ; \mathrm{NPC} M=3.16 ; \delta=0.57$ ) and "Affiliative" (NPP M = 3.71; $\mathrm{NPC} \mathrm{M}=3.26 ; \delta=0.52$ ) styles. In both "Defensive" styles, NPP score lower than NPC in "Conventional" (NPP $\mathrm{M}=3.27 ; \mathrm{NPC} \mathrm{M}=3.41 ; \delta=-0.22)$, "Avoidance" (NPP $\mathrm{M}=2.25 ; \mathrm{NPC} \mathrm{M}=2.48 ; \delta=-0.32$ ), "Oppositional" (NPP M $=2.79 ; \mathrm{NPC} M=2.69 ; \delta=0.22$ ) and "Competitive" (NPP M = 2.10; NPC $\mathrm{M}=2.36 ; \delta=-0.31$ ) styles, (Table 5; Figure 5).

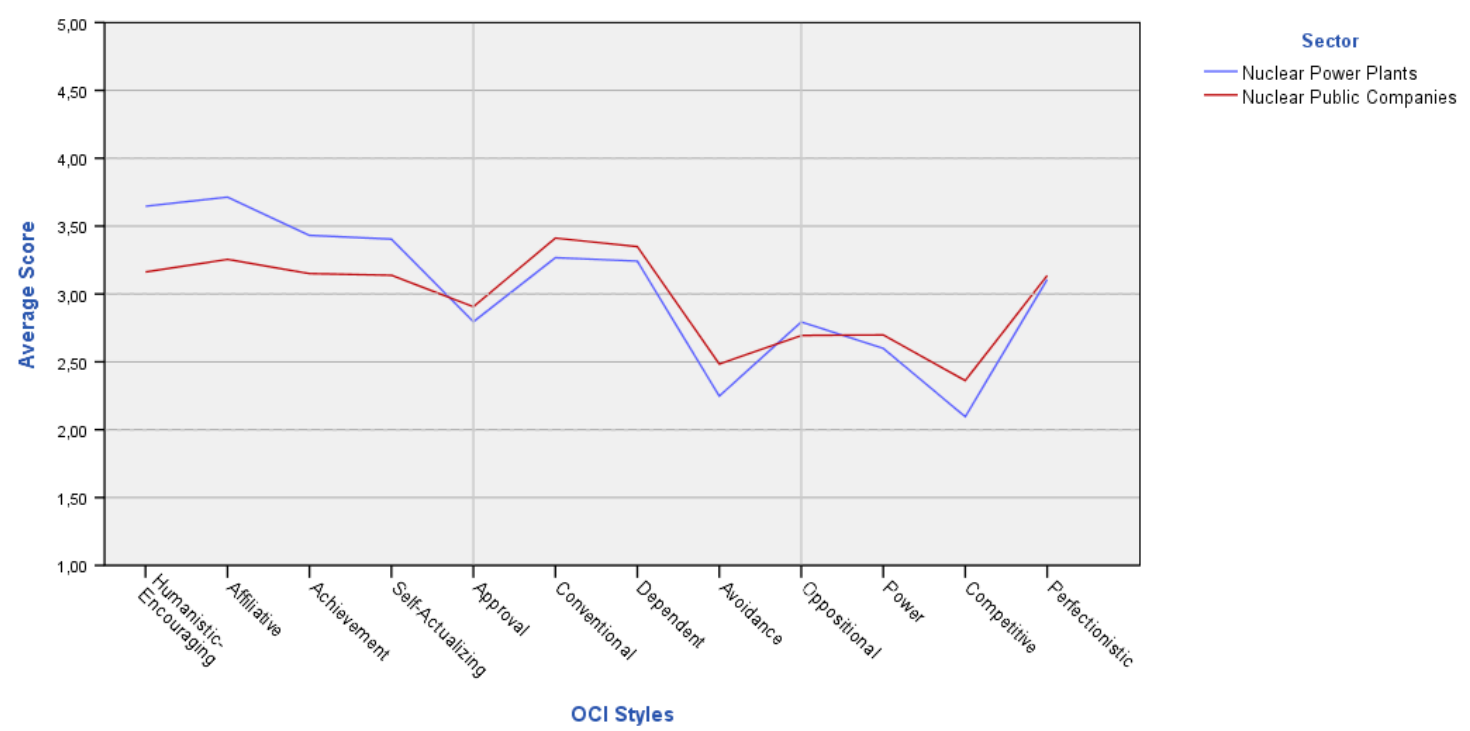

Figure 5. OCI styles averages for Spanish nuclear sector.

If only NPP are considered (Table 6a), the statistical analysis shows very compact results within the "Constructive" organizational culture, with only a single difference of a small effect size $(\delta=-0.24)$ 
between two stations. Within "Defensive" organizational cultures, there are more differences between the stations, although with small effect sizes.

Table 6. OCI organizational cultures averages and effect sizes for (a) nuclear power plants (NPP) and for (b) nuclear public companies (NPC).

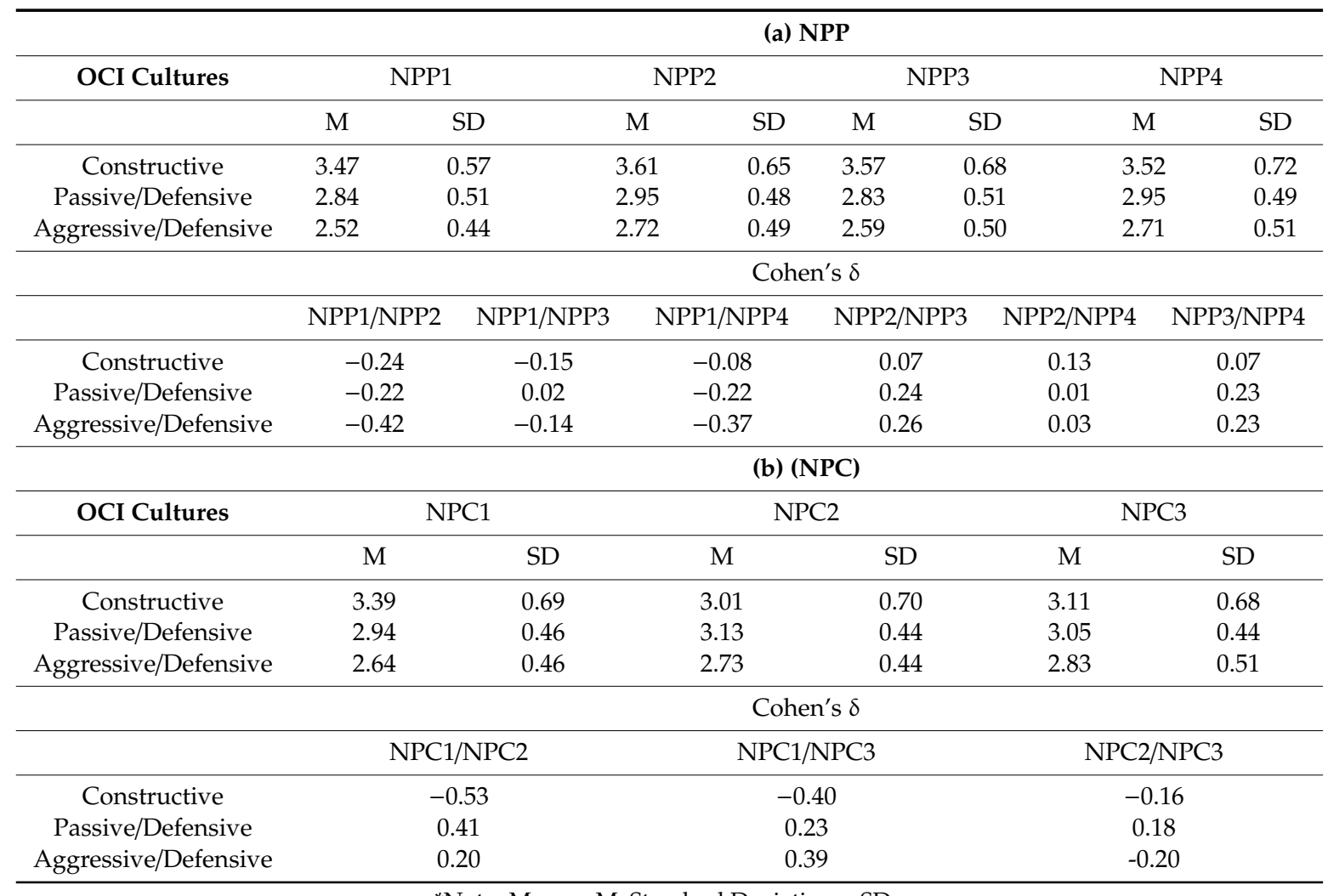

${ }^{*}$ Note: Mean $=\mathrm{M}$; Standard Deviation $=\mathrm{SD}$.

Results also show differences of small or medium effect size between NPC1 and both NPC2 and NPC3 organizations in all three OCI cultures (Table 6b).

\subsubsection{Differences by Work Location (Facility vs. Headquarters)}

Considering NPP and NPC together, facility personnel score higher than headquarters personnel in the "Constructive" cluster (facility $\mathrm{M}=3.52$; headquarters $\mathrm{M}=3.34 ; \delta=0.26$ ) (Table 7; Figure 6).

Within the "Defensive" clusters, there are no relevant work location-based differences, except in the "Oppositional" style (facility $\mathrm{M}=2.79$; headquarters $\mathrm{M}=2.67 ; \delta=0.26$ ) (Table 7; Figure 7).

If only NPP are considered, there are no differences by work location in the "Constructive" organizational culture, but facility personnel score higher in" Defensive" cultures (Table 7).

On the contrary, in NPC there are differences in work location in the "Constructive" organizational culture (Table 7). Personnel working onsite perceive a more "Constructive" culture (facility $\mathrm{M}=3.28$; headquarters $\mathrm{M}=3.03 ; \delta=0.36$ ). There are also differences in the "Aggressive/Defensive", "Oppositional" (facility $\mathrm{M}=2.74$; headquarters $\mathrm{M}=2.56 ; \delta=0.40$ ) and "Perfectionistic" styles (facility $\mathrm{M}=3.13$; headquarters $\mathrm{M}=3.01 ; \delta=0.21$ ), with facility personnel scoring higher. There are no work location-based differences in the "Passive/Defensive" styles. 
Table 7. Descriptive statistics of the OCI organizational cultures and styles by work location.

\begin{tabular}{|c|c|c|c|c|c|c|c|c|c|c|c|c|c|c|c|}
\hline \multirow[b]{3}{*}{ OCI Styles } & \multicolumn{5}{|c|}{ Spanish Nuclear Industry } & \multicolumn{5}{|c|}{ NPP } & \multicolumn{5}{|c|}{ NPC } \\
\hline & \multicolumn{2}{|c|}{ Facility } & \multicolumn{2}{|c|}{ Headq. } & \multirow[b]{2}{*}{ Cohen's $\delta$} & \multicolumn{2}{|c|}{ Facility } & \multicolumn{2}{|c|}{ Headq. } & \multirow[b]{2}{*}{ Cohen's $\delta$} & \multicolumn{2}{|c|}{ Facility } & \multicolumn{2}{|c|}{ Headq. } & \multirow[b]{2}{*}{ Cohen's $\delta$} \\
\hline & $\mathbf{M}$ & SD & $\mathbf{M}$ & SD & & $\mathbf{M}$ & SD & $\mathbf{M}$ & SD & & $\mathbf{M}$ & SD & $\mathbf{M}$ & SD & \\
\hline Humanistic-Encouraging & 3.61 & 0.85 & 3.38 & 0.92 & 0.27 & 3.65 & 0.85 & 3.61 & 0.82 & 0.05 & 3.30 & 0.82 & 2.98 & 0.93 & 0.38 \\
\hline Affiliative & 3.69 & 0.89 & 3.43 & 0.90 & 0.29 & 3.73 & 0.90 & 3.62 & 0.85 & 0.13 & 3.38 & 0.80 & 3.11 & 0.89 & 0.32 \\
\hline Achievement & 3.40 & 0.61 & 3.30 & 0.71 & 0.16 & 3.43 & 0.60 & 3.46 & 0.63 & -0.04 & 3.20 & 0.64 & 3.04 & 0.77 & 0.24 \\
\hline Self-Actualizing & 3.39 & 0.70 & 3.25 & 0.78 & 0.20 & 3.41 & 0.70 & 3.40 & 0.72 & 0.01 & 3.25 & 0.71 & 2.98 & 0.80 & 0.35 \\
\hline Approval & 2.83 & 0.64 & 2.70 & 0.63 & 0.21 & 2.82 & 0.65 & 2.60 & 0.61 & 0.34 & 2.91 & 0.54 & 2.86 & 0.63 & 0.09 \\
\hline Conventional & 3.30 & 0.65 & 3.26 & 0.69 & 0.05 & 3.28 & 0.66 & 3.16 & 0.68 & 0.18 & 3.40 & 0.59 & 3.44 & 0.68 & -0.06 \\
\hline Dependent & 3.26 & 0.56 & 3.24 & 0.57 & 0.04 & 3.25 & 0.56 & 3.16 & 0.57 & 0.16 & 3.34 & 0.52 & 3.38 & 0.56 & -0.07 \\
\hline Avoidance & 2.28 & 0.74 & 2.26 & 0.74 & 0.03 & 2.26 & 0.75 & 2.11 & 0.67 & 0.21 & 2.42 & 0.69 & 2.51 & 0.78 & -0.13 \\
\hline Oppositional & 2.79 & 0.46 & 2.67 & 0.43 & 0.26 & 2.80 & 0.47 & 2.74 & 0.41 & 0.14 & 2.74 & 0.45 & 2.56 & 0.45 & 0.40 \\
\hline Power & 2.62 & 0.64 & 2.56 & 0.65 & 0.08 & 2.61 & 0.65 & 2.49 & 0.64 & 0.19 & 2.66 & 0.59 & 2.69 & 0.66 & -0.05 \\
\hline Competitive & 2.13 & 0.87 & 2.03 & 0.84 & 0.12 & 2.12 & 0.89 & 1.91 & 0.84 & 0.24 & 2.28 & 0.71 & 2.25 & 0.79 & 0.03 \\
\hline Perfectionistic & 3.11 & 0.61 & 3.06 & 0.61 & 0.09 & 3.11 & 0.61 & 3.09 & 0.62 & 0.04 & 3.13 & 0.57 & 3.01 & 0.60 & 0.21 \\
\hline Constructive & 3.52 & 0.69 & 3.34 & 0.77 & 0.26 & 3.55 & 0.69 & 3.52 & 0.69 & 0.05 & 3.28 & 0.67 & 3.03 & 0.79 & 0.36 \\
\hline Passive/Defensive & 2.92 & 0.49 & 2.86 & 0.53 & 0.11 & 2.90 & 0.50 & 2.76 & 0.51 & 0.29 & 3.02 & 0.42 & 3.05 & 0.54 & -0.06 \\
\hline Aggressive/Defensive & 2.67 & 0.49 & 2.58 & 0.48 & 0.17 & 2.66 & 0.50 & 2.56 & 0.49 & 0.21 & 2.70 & 0.43 & 2.63 & 0.47 & 0.16 \\
\hline
\end{tabular}

${ }^{*}$ Note: Mean $=$ M; Standard Deviation $=$ SD; Sample $=$ N. 


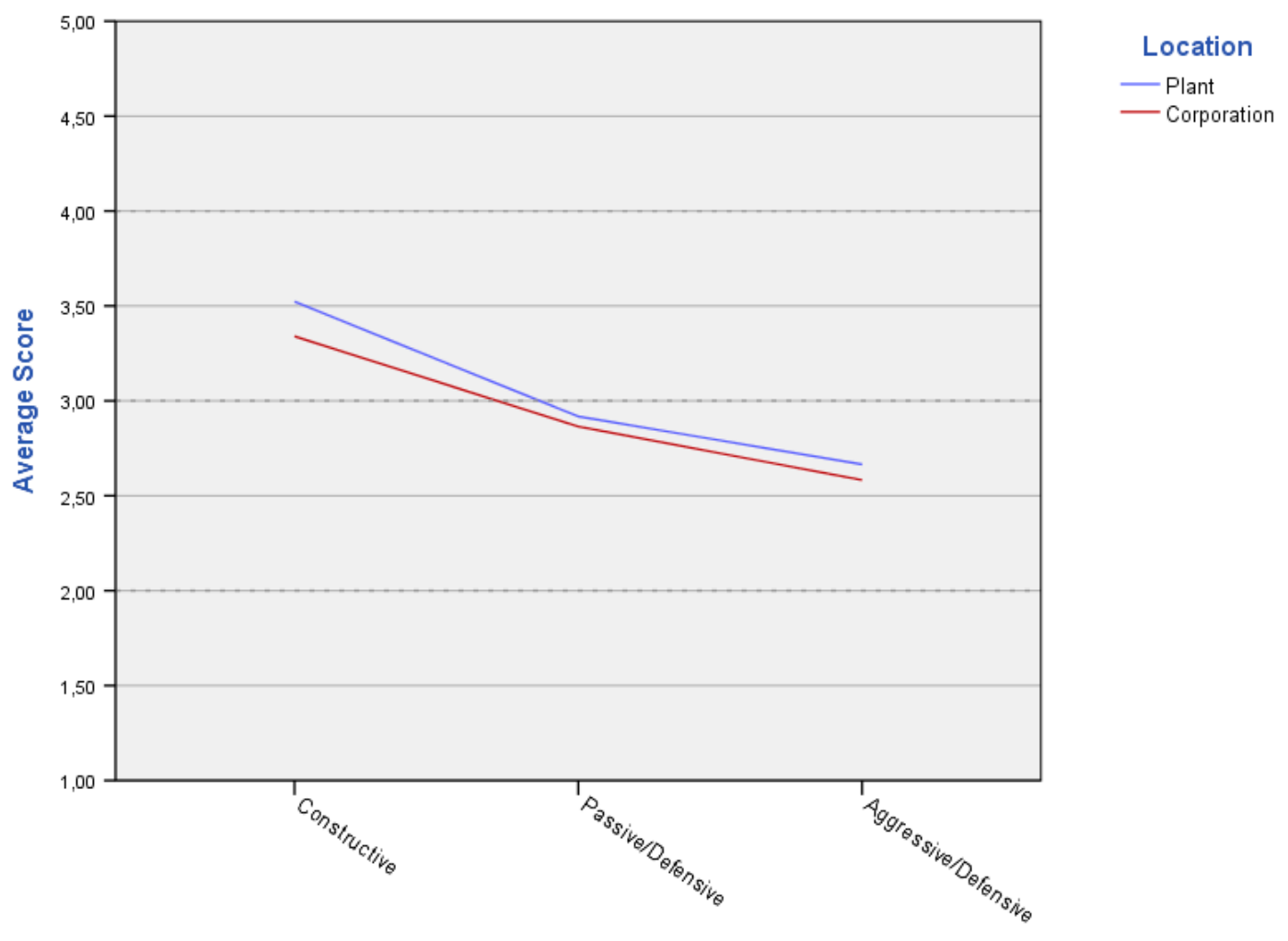

Organizational Cultures

Figure 6. OCI organizational cultures averages by work location.

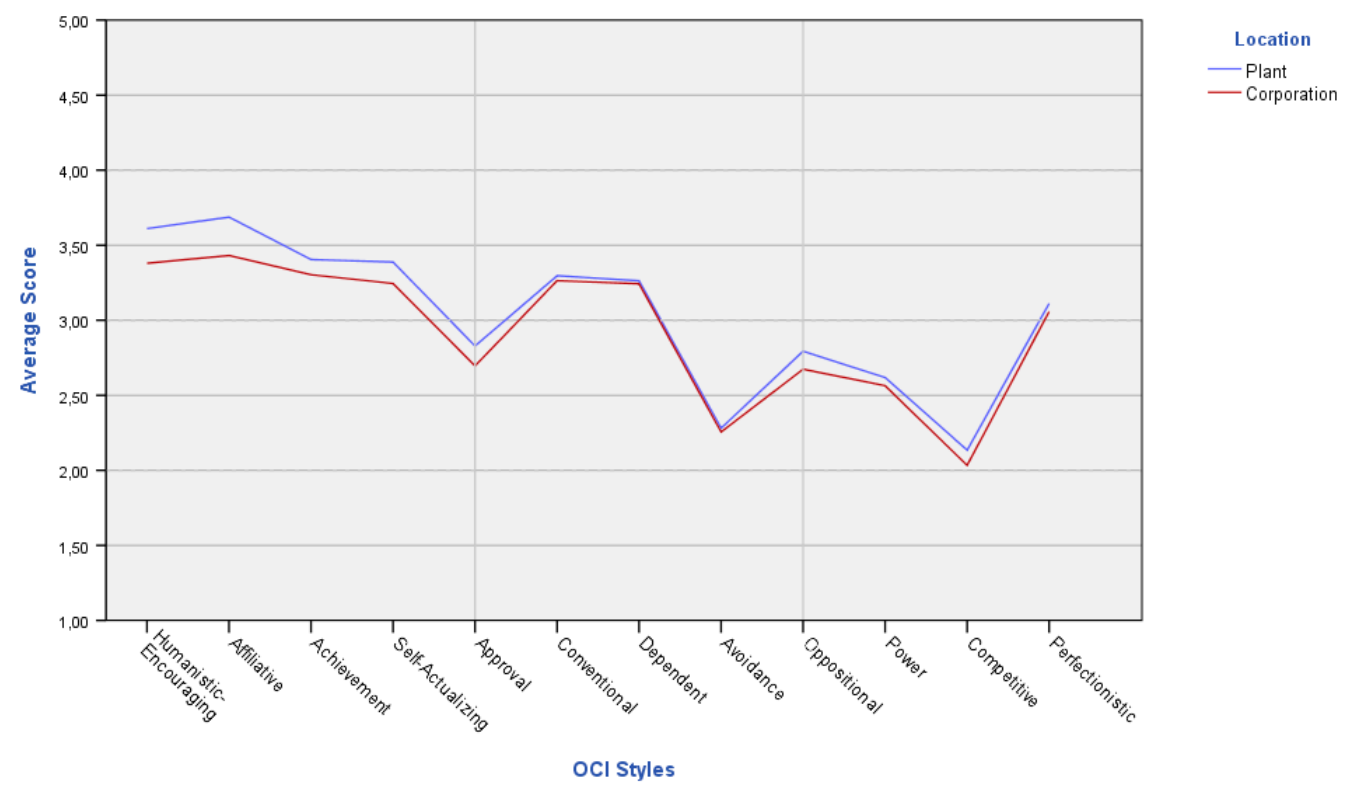

Figure 7. OCI styles averages by work location.

\subsubsection{Differences by Contractual Relationship (Own Staff vs. Contractor)}

Considering NPP and NPC together, results show homogeneity of scores in all three OCI types of culture between own staff and contractors (Table 8; Figure 8). There is only a small difference in the "Affiliative" style of the "Constructive" cluster (own staff $\mathrm{M}=3.54$; contractor $\mathrm{M}=3.73 ; \delta=-0.21$ ) (Table 8; Figure 9). 
Table 8. Descriptive statistics of the OCI organizational cultures and styles by contractual relationship.

\begin{tabular}{|c|c|c|c|c|c|c|c|c|c|c|c|c|c|c|c|}
\hline \multirow[b]{3}{*}{ OCI Styles } & \multicolumn{5}{|c|}{ Spanish Nuclear Industry } & \multicolumn{5}{|c|}{ NPP } & \multicolumn{5}{|c|}{ NPC } \\
\hline & \multicolumn{2}{|c|}{ Own Staff } & \multicolumn{2}{|c|}{ Contractor } & \multirow[b]{2}{*}{ Cohen's $\delta$} & \multicolumn{2}{|c|}{ Own Staff } & \multicolumn{2}{|c|}{ Contractor } & \multirow[b]{2}{*}{ Cohen's $\delta$} & \multicolumn{2}{|c|}{ Own Staff } & \multicolumn{2}{|c|}{ Contractor } & \multirow[b]{2}{*}{ Cohen's 8} \\
\hline & $\mathbf{M}$ & SD & $\mathbf{M}$ & SD & & $\mathbf{M}$ & SD & $\mathbf{M}$ & SD & & $\mathbf{M}$ & SD & $\mathbf{M}$ & SD & \\
\hline Humanistic-Encouraging & 3.50 & 0.88 & 3.63 & 0.85 & -0.15 & 3.70 & 0.81 & 3.63 & 0.86 & 0.09 & 3.10 & 0.86 & 3.63 & 0.74 & -0.62 \\
\hline Affiliative & 3.54 & 0.88 & 3.73 & 0.91 & -0.21 & 3.72 & 0.85 & 3.73 & 0.91 & -0.02 & 3.20 & 0.85 & 3.66 & 0.76 & -0.54 \\
\hline Achievement & 3.36 & 0.63 & 3.39 & 0.61 & -0.05 & 3.49 & 0.58 & 3.39 & 0.61 & 0.16 & 3.12 & 0.67 & 3.35 & 0.60 & -0.35 \\
\hline Self-Actualizing & 3.34 & 0.72 & 3.38 & 0.70 & -0.06 & 3.46 & 0.68 & 3.37 & 0.70 & 0.13 & 3.09 & 0.73 & 3.48 & 0.70 & -0.53 \\
\hline Approval & 2.78 & 0.62 & 2.84 & 0.64 & -0.09 & 2.73 & 0.64 & 2.84 & 0.64 & -0.17 & 2.90 & 0.57 & 2.89 & 0.56 & 0.02 \\
\hline Conventional & 3.29 & 0.66 & 3.29 & 0.66 & 0.00 & 3.23 & 0.66 & 3.29 & 0.66 & -0.10 & 3.43 & 0.63 & 3.30 & 0.57 & 0.21 \\
\hline Dependent & 3.27 & 0.54 & 3.24 & 0.57 & 0.05 & 3.23 & 0.54 & 3.24 & 0.57 & -0.02 & 3.36 & 0.53 & 3.27 & 0.54 & 0.16 \\
\hline Avoidance & 2.29 & 0.72 & 2.28 & 0.77 & 0.01 & 2.17 & 0.69 & 2.28 & 0.77 & -0.15 & 2.51 & 0.73 & 2.23 & 0.64 & 0.39 \\
\hline Oppositional & 2.75 & 0.44 & 2.80 & 0.49 & -0.11 & 2.80 & 0.42 & 2.80 & 0.49 & -0.02 & 2.67 & 0.45 & 2.83 & 0.44 & -0.36 \\
\hline Power & 2.60 & 0.64 & 2.62 & 0.65 & -0.04 & 2.55 & 0.63 & 2.62 & 0.65 & -0.12 & 2.71 & 0.64 & 2.58 & 0.57 & 0.20 \\
\hline Competitive & 2.12 & 0.84 & 2.16 & 0.91 & -0.05 & 1.98 & 0.82 & 2.16 & 0.92 & -0.21 & 2.38 & 0.80 & 2.14 & 0.65 & 0.30 \\
\hline Perfectionistic & 3.15 & 0.59 & 3.07 & 0.63 & 0.13 & 3.14 & 0.58 & 3.07 & 0.63 & 0.12 & 3.15 & 0.61 & 3.03 & 0.55 & 0.20 \\
\hline Constructive & 3.44 & 0.71 & 3.53 & 0.69 & -0.14 & 3.59 & 0.66 & 3.53 & 0.69 & 0.09 & 3.13 & 0.71 & 3.53 & 0.62 & -0.57 \\
\hline Passive/Defensive & 2.91 & 0.50 & 2.91 & 0.49 & -0.01 & 2.84 & 0.50 & 2.91 & 0.50 & -0.15 & 3.05 & 0.46 & 2.92 & 0.40 & 0.28 \\
\hline Aggressive/Defensive & 2.65 & 0.48 & 2.66 & 0.52 & -0.02 & 2.61 & 0.47 & 2.66 & 0.52 & -0.10 & 2.73 & 0.48 & 2.65 & 0.42 & 0.18 \\
\hline
\end{tabular}

${ }^{*}$ Note: Mean = M; Standard Deviation = SD. 


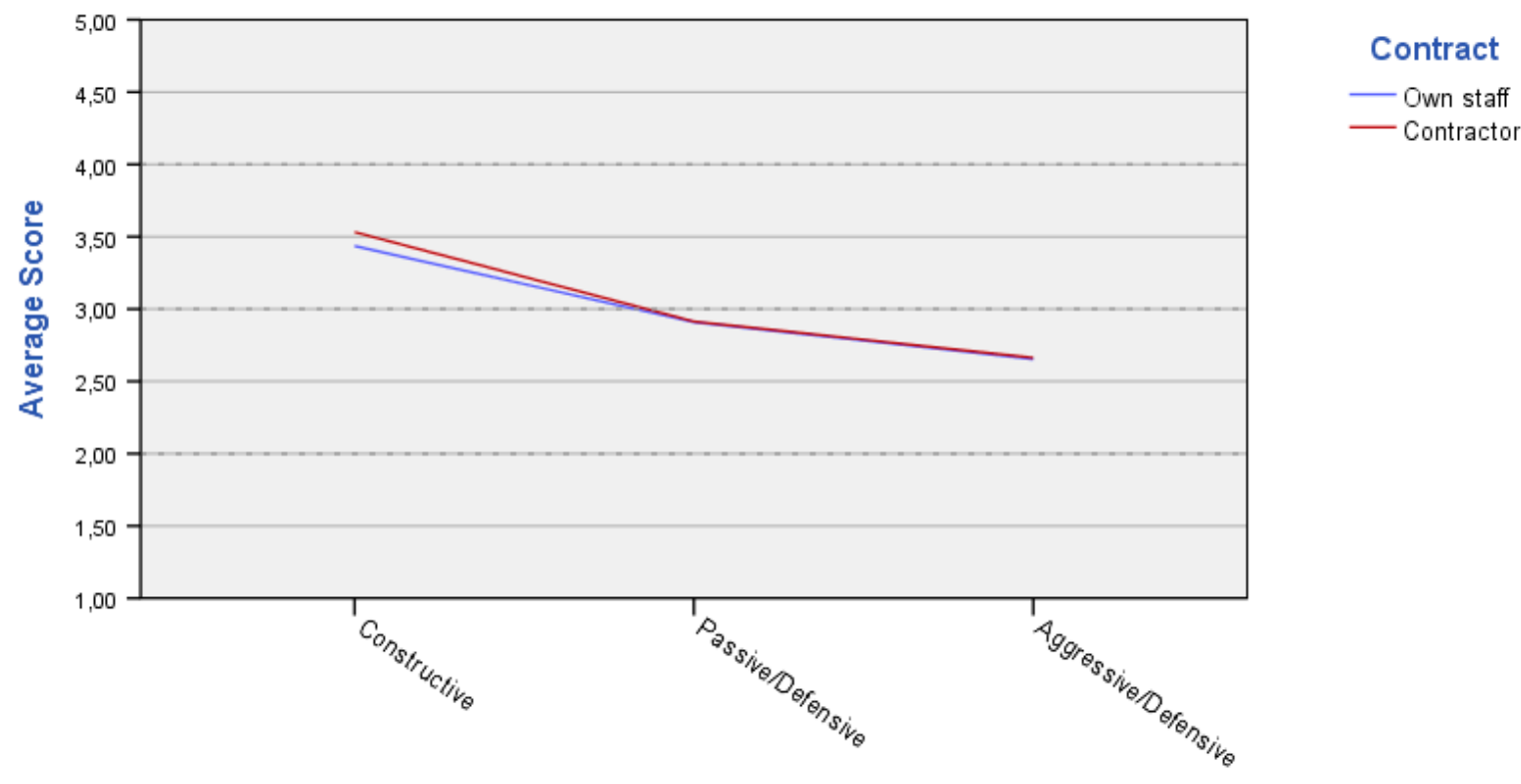

Organizational Cultures

Figure 8. OCI organizational cultures averages by contractual relationship.

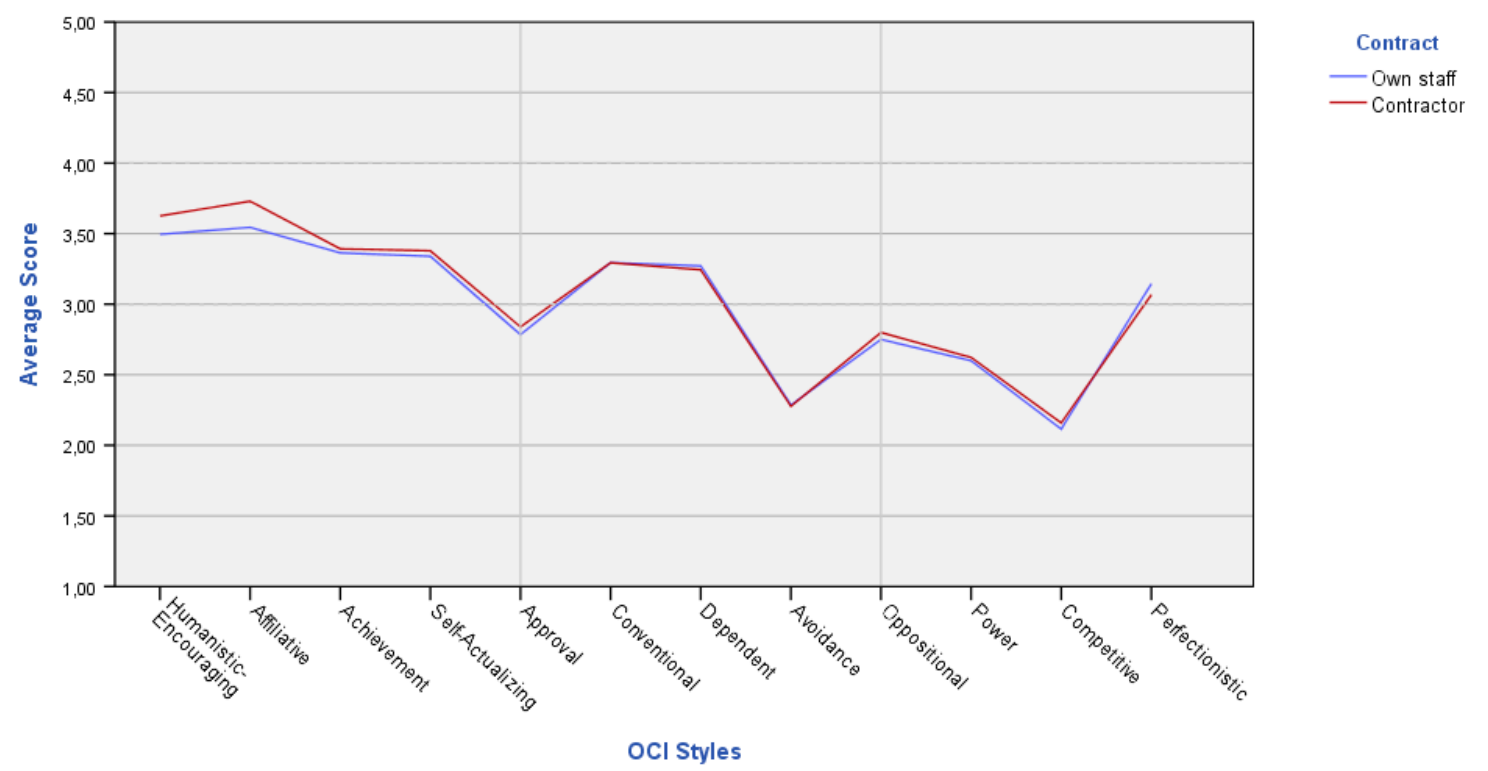

Figure 9. OCI styles averages by contractual relationship.

There are no differences in any of the three OCI organizational cultures by contractual relationship in NPP, with the only exception of a small one in the "Competitive" style in which contractor personnel score higher than own staff (own staff $\mathrm{M}=1.98$; contractor $\mathrm{M}=2.16 ; \delta=-0.21$ ), (NPP; Table 8).

In NPC, contractor personnel score higher than own staff in the "Constructive" organizational culture (own staff $\mathrm{M}=3.13$; contractor $\mathrm{M}=3.53 ; \delta=-0.57$ ). The norms with the highest differences are "Humanistic-Encouraging" ( $\delta=0.62)$, "Affiliative" $(\delta=0.54)$ and" Self-Actualizing" $(\delta=0.53)$. Similarly, contractor personnel scores lower in the "Passive/Defensive" organizational culture (own staff $\mathrm{M}=3.05$; contractor $\mathrm{M}=2.92 ; \delta=0.28$ ). Regarding "Defensive" styles, there are small size differences in the "Conventional", "Avoidance", "Oppositional", "Competitive" and "Perfectionistic" 
styles, with contractors scoring lower in all of them, except in the "Oppositional" style. It is worth mentioning that in this case, the analysis was only carried out in one organization (NPC; Table 8).

Key study findings by demographic variables are summarized in Table 9.

Table 9. Main findings.

\begin{tabular}{|c|c|c|c|}
\hline & Spanish Nuclear Industry & Nuclear Power Plants & Nuclear Public Companies \\
\hline Sector & $\begin{array}{l}\text { The dominant cultural style is } \\
\text { "Constructive" (3.47), followed } \\
\text { by "Passive/Defensive" (2.91) } \\
\text { and "Aggressive/Defensive" } \\
\text { (2.66). } \\
\text { The main differences in this } \\
\text { survey are found in the } \\
\text { "Humanistic-Encouraging" } \\
\text { and "Affiliative" styles. }\end{array}$ & $\begin{array}{l}\text { Homogeneity between } \\
\text { plants in the } \\
\text { "Constructive" culture. } \\
\text { Differences between } \\
\text { plants in the "Defensive" } \\
\text { cultures. }\end{array}$ & $\begin{array}{l}\text { Differences between } \\
\text { organizations in the } \\
\text { "Constructive" style (medium } \\
\text { effect size } \delta=0.53 \text { ). Multiple } \\
\text { differences in terms of styles. }\end{array}$ \\
\hline Location & $\begin{array}{l}\text { Facility personnel score higher } \\
\text { in the "Constructive" culture } \\
\text { than headquarters personnel. }\end{array}$ & $\begin{array}{l}\text { Facility personnel have } \\
\text { higher scores in the } \\
\text { "Defensive" style than } \\
\text { headquarters personnel. }\end{array}$ & $\begin{array}{l}\text { Headquarters personnel have } \\
\text { higher scores in the } \\
\text { "Constructive" culture than } \\
\text { facility personnel. }\end{array}$ \\
\hline $\begin{array}{l}\text { Contractual } \\
\text { relationship }\end{array}$ & $\begin{array}{l}\text { No differences in terms of } \\
\text { contractual relationship. }\end{array}$ & $\begin{array}{l}\text { No differences in terms } \\
\text { of contractual } \\
\text { relationship. }\end{array}$ & $\begin{array}{l}\text { Results obtained from one } \\
\text { single organization. } \\
\text { Contractors score higher in the } \\
\text { "Constructive" culture. } \\
\text { The largest size magnitude in } \\
\text { the survey is in the } \\
\text { "Humanistic-Encouraging" } \\
\text { ( } \delta=0.62) \text { style. }\end{array}$ \\
\hline
\end{tabular}

\subsubsection{Differences by Mintzberg's Organizational Components}

Table 10 shows statistical data for the analysis of cultural styles according to Mintzberg's model.

The "Constructive" cluster score is homogeneous in all five organizational components (Figure 10). Although strategic apex and support staff in the "Constructive" cluster have a higher score than middle line, operating core and technostructure, differences are not statistically significant. Such homogeneity does not exist in the "Defensive" styles, where technostructure and strategic apex personnel have similar scores in both "Defensive" clusters and support staff and middle line in the "Aggressive/Defensive" cluster, although with statistically significant differences between technostructure and operating core. Operating core personnel have higher scores than technostructure personnel in the "Passive/Defensive" cluster $(\mathrm{t}(167)=3.46 ; p=0.007 ; \mathrm{d}=0.31 ; 95 \% \mathrm{CI}: 0.06,0.57)$ and "Aggressive/Defensive" cluster $(\mathrm{t}(167)=2.93 ; p=0.039 ; \mathrm{d}=0.24 ; 95 \%$ CI: $0.01,0.47)$.

When comparing component results for the twelve OCI styles (Table 10b-d), statistically significant differences are observed in the "Defensive" styles for "Approval", "Avoidance" and "Perfectionistic" (Figure 11). Operating core personnel have a higher score than technostructure personnel in the styles "Approval" $(\mathrm{t}(167)=3.00 ; p=0.027 ; \mathrm{d}=0.36 ; 95 \% \mathrm{CI}=0.02,0.69)$, "Avoidance" $(\mathrm{t}(167)=3.82 ; p=0.003$; $\mathrm{d}=0.42 ; 95 \% \mathrm{CI}=0.10,0.74)$ and "Perfectionistic" $(\mathrm{t}(167)=2.9 ; p=0.031 ; \mathrm{d}=0.29 ; 95 \% \mathrm{CI}=0.02$, 0.56). Similarly, support personnel perceive a more "Approval"-based culture than technostructure personnel $(\mathrm{t}(106)=3.15 ; p=0.016 ; \mathrm{d}=0.41 ; 95 \% \mathrm{CI}=0.05,0.77)$. 
Table 10. Descriptive statistics by Mintzberg's components of the (a) OCI organizational cultures; (b) OCI "Constructive" styles; (c) OCI "Passive/Defensive" styles and (d) OCI "Aggressive/Defensive" styles *.

\begin{tabular}{|c|c|c|c|c|c|c|c|c|c|c|c|c|c|}
\hline \multirow[b]{3}{*}{$\begin{array}{l}\text { Mintzberg } \\
\text { Component }\end{array}$} & \multirow[b]{3}{*}{$\mathrm{N}$} & \multicolumn{12}{|c|}{ (a) Organizational cultures } \\
\hline & & \multicolumn{4}{|c|}{ Constructive } & \multicolumn{5}{|c|}{ Passive/Defensive } & \multicolumn{3}{|c|}{ Aggressive/Defensive } \\
\hline & & & M & SD & Sig & \multicolumn{2}{|c|}{ M } & \multicolumn{2}{|l|}{ SD } & Sig & M & SD & Sig \\
\hline a Strategic Apex & 14 & & 3.59 & 0.54 & & \multicolumn{2}{|c|}{2.57} & \multicolumn{2}{|l|}{0.33} & & 2.38 & 0.29 & \\
\hline b Middle Line & 27 & & 3.45 & 0.51 & & \multicolumn{2}{|c|}{2.77} & \multicolumn{2}{|l|}{0.52} & & 2.46 & 0.37 & \\
\hline c Operating Core & 133 & & 3.44 & 0.53 & & \multicolumn{2}{|c|}{2.92} & \multicolumn{2}{|l|}{0.50} & $\mathrm{~d}$ & 2.61 & 0.43 & d \\
\hline d Technostructure & 36 & & 3.43 & 0.75 & & \multicolumn{2}{|c|}{2.61} & \multicolumn{2}{|l|}{0.46} & c & 2.38 & 0.41 & c \\
\hline e Support Staff & 72 & & 3.58 & 0.56 & & \multicolumn{2}{|c|}{2.88} & 0.47 & & & 2.47 & 0.50 & \\
\hline Total & 282 & & 3.48 & 0.57 & & 2.8 & & 0.49 & & & 2.52 & 0.44 & \\
\hline & & & & & & & Constru & Ictive $s$ & tyles & & & & \\
\hline & & & $\begin{array}{l}\text { Humar } \\
\text { Encour }\end{array}$ & & & Affiliat & & & chieve & vement & & elf-Actua & lizing \\
\hline $\begin{array}{c}\text { Mintzberg } \\
\text { Component }\end{array}$ & $\mathrm{N}$ & M & SD & Sig & M & SD & Sig & $\mathrm{M}$ & & SD & Sig & SD & Sig \\
\hline a Strategic Apex & 14 & 3.81 & 0.65 & & 3.52 & 0.58 & & 3.5 & & 0.52 & 3.4 & 0.6 & \\
\hline b Middle Line & 27 & 3.57 & 0.71 & & 3.53 & 0.63 & & 3.3 & & 0.37 & 3.3 & 0.5 & \\
\hline c Operating Core & 133 & 3.47 & 0.67 & & 3.52 & 0.67 & & 3.3 & & 0.47 & 3.4 & 0.5 & \\
\hline d Technostructure & 36 & 3.52 & 0.84 & & 3.50 & 0.94 & & 3.3 & & 0.65 & 3.3 & 0.7 & \\
\hline e Support Staff & 72 & 3.64 & 0.69 & & 3.76 & 0.66 & & 3.4 & & 0.54 & 3.5 & 0.6 & \\
\hline Total & 282 & 3.55 & 0.70 & & 3.58 & 0.70 & & 3.3 & & 0.51 & 3.4 & 0.63 & \\
\hline & & & & & & (c) $\mathrm{Pa}$ & sive/D & fensiv & e Style & & & & \\
\hline & & & Appr & & & onventi & onal & & epend & dent & & Avoidan & \\
\hline $\begin{array}{l}\text { Mintzberg } \\
\text { Component }\end{array}$ & $\mathrm{N}$ & M & SD & Sig & M & SD & Sig & M & SD & Sig & M & SD & Sig \\
\hline a Strategic Apex & 14 & 2.43 & 0.57 & & 2.92 & 0.47 & & 3.08 & 0.48 & & 1.84 & 0.35 & \\
\hline b Middle Line & 27 & 2.64 & 0.68 & & 3.15 & 0.65 & & 3.14 & 0.56 & & 2.14 & 0.67 & \\
\hline c Operating Core & 133 & 2.82 & 0.63 & $\mathrm{~d}$ & 3.31 & 0.63 & & 3.27 & 0.55 & & 2.26 & 0.63 & $\mathrm{~d}$ \\
\hline d Technostructure & 36 & 2.47 & 0.59 & $\mathrm{c} / \mathrm{e}$ & 3.00 & 0.55 & & 3.12 & 0.51 & & 1.84 & 0.60 & c \\
\hline e Support Staff & 72 & 2.87 & 0.63 & $\mathrm{~d}$ & 3.25 & 0.60 & & 3.28 & 0.54 & & 2.09 & 0.59 & \\
\hline Total & 282 & 2.75 & 0.64 & & 3.22 & 0.62 & & 3.23 & 0.54 & & 2.13 & 0.62 & \\
\hline & & & & & & (d) Agg & ressive/ & Defens & ive St & tyles & & & \\
\hline & & & Opposi & nal & & Powe & & & mpeti & titive & & erfection & stic \\
\hline $\begin{array}{l}\text { Mintzberg } \\
\text { Component }\end{array}$ & $\mathrm{N}$ & M & SD & Sig & M & SD & Sig & M & SD & Sig & M & SD & Sig \\
\hline a Strategic Apex & 14 & 2.71 & 0.34 & & 2.29 & 0.41 & & 1.63 & 0.61 & & 2.88 & 0.44 & \\
\hline b Middle Line & 27 & 2.73 & 0.39 & & 2.36 & 0.53 & & 1.81 & 0.64 & & 2.94 & 0.44 & \\
\hline c Operating Core & 133 & 2.79 & 0.41 & & 2.46 & 0.59 & & 2.02 & 0.68 & & 3.18 & 0.53 & d \\
\hline d Technostructure & 36 & 2.60 & 0.33 & & 2.24 & 0.59 & & 1.77 & 0.60 & & 2.89 & 0.53 & c \\
\hline e Support Staff & 72 & 2.69 & 0.46 & & 2.28 & 0.65 & & 1.94 & 0.73 & & 2.97 & 0.53 & \\
\hline Total & 282 & 2.73 & 0.41 & & 2.37 & 0.60 & & 1.93 & 0.68 & & 3.05 & 0.53 & \\
\hline
\end{tabular}

*Note: Mean = M; Standard Deviation = SD; Sample = N; Significance = Sig. "Sig" columns contain the codes of the Mintzberg's organizational components with statistically significant differences (Bonferroni-corrected $p<0.05$ ). 


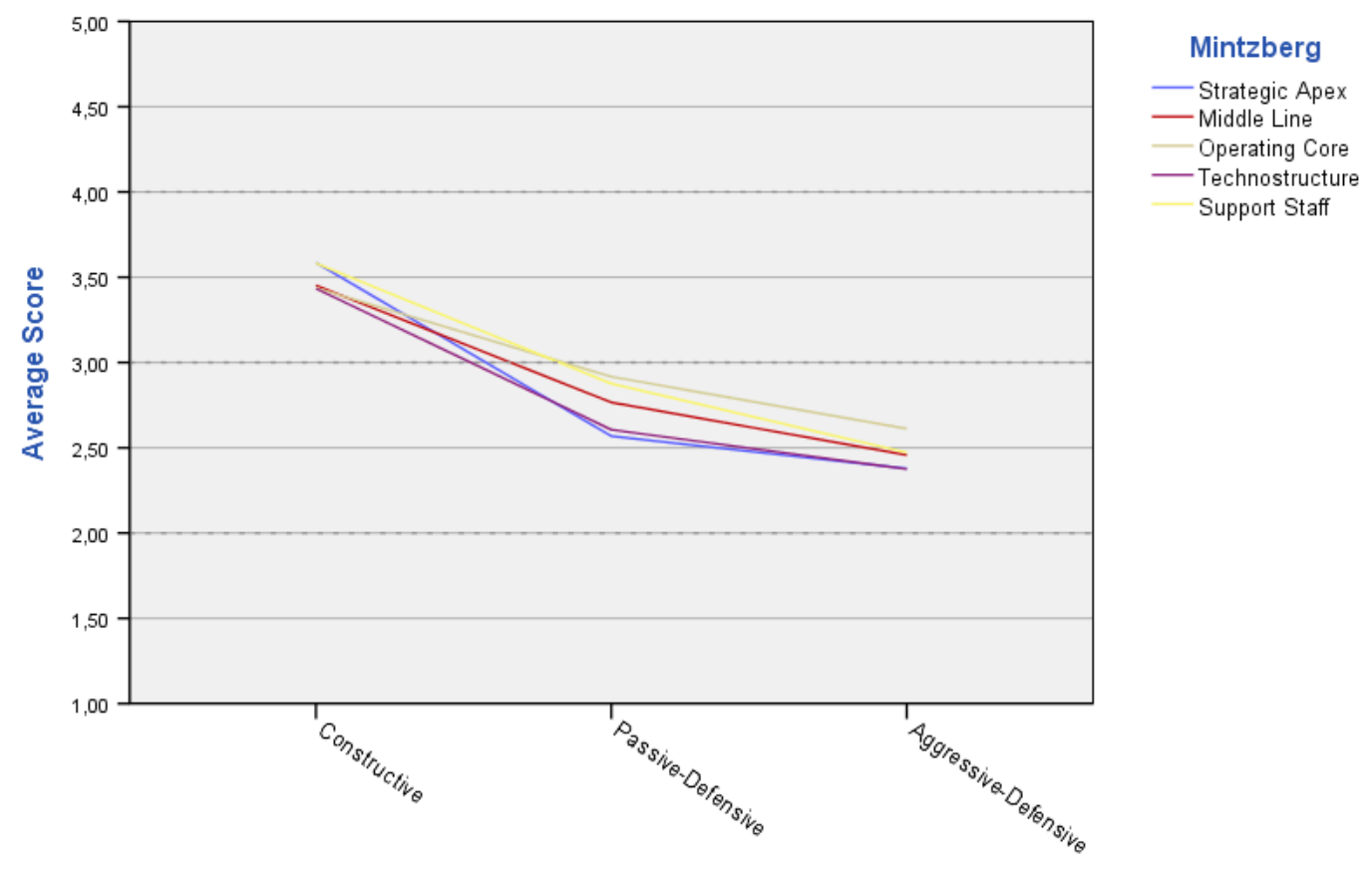

Organizational Cultures

Figure 10. OCI organizational cultures averages by Mintzberg's organizational components.

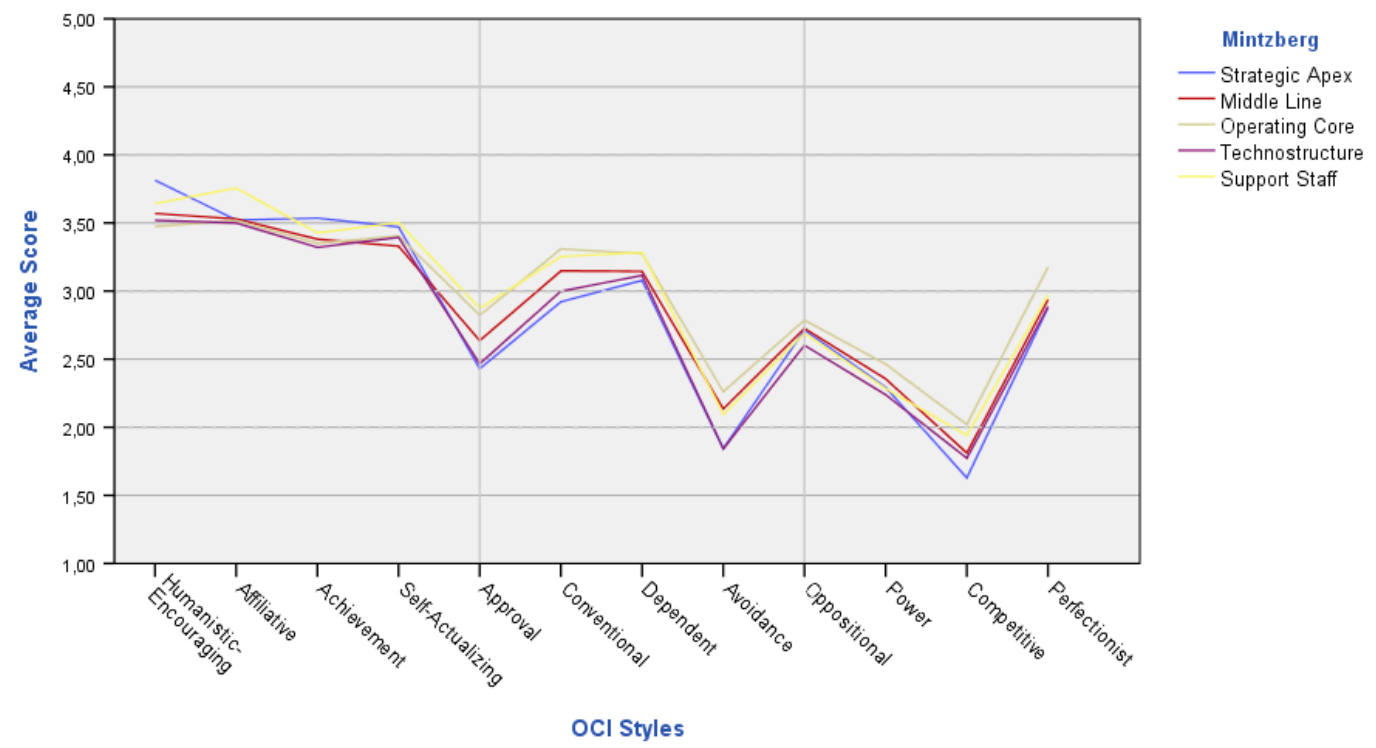

Figure 11. OCI styles averages by Mintzberg's organizational components.

\section{Discussion}

This paper describes the organizational culture of the Spanish nuclear industry based on OCI survey responses from independent safety culture evaluations carried out over the last decade in companies within the nuclear sector. Such evaluations also allow exploring the existence (or lack thereof) of organizational subcultures depending on the type of organization (nuclear power plant or other types of nuclear companies), workplace (facility or headquarters), contractual relationship (own staff or contractor) and organizational components according to Mintzberg's theory. 


\subsection{Organizational Culture of the Spanish Nuclear Industry}

According to Schein [20], organizational culture is defined as shared basic assumptions influencing the way in which organization members feel and act. It is also an essential element for the safety of high-risk organizations. Investigations carried out after severe nuclear accidents have shown the relevance of culture and organizational factors on safety [16-18]. Similarly, organizational culture is not necessarily a single construct, as it can comprise a number of subcultures $[8,9,20-22,24,25]$.

The first relevant result of this study is the identification of two main traits defining the organizational culture of Spanish nuclear organizations. In OCI terms, the first trait of the sector's organizational culture is mainly "Constructive". It is a type of organizational culture aimed at ensuring excellence and achieving results in a manner compatible with the well-being and professional development of personnel. High scores in the "Affiliative" style also reflect a special focus on the promotion of interpersonal collaborative relationships, thus favoring satisfaction within the work group.

The second trait defining the organizational culture of the Spanish nuclear industry is determined by high scores in some "Defensive" styles within the OCI. More specifically, it is a culture fostering behaviors of a "Conventional", "Dependent" and "Perfectionistic" nature, and therefore encouraging workers to seek the rules and obey them; seek to be guided; and wait for orders instead of having initiatives. It is worth noting the relevance of this second feature of the global culture of the nuclear industry considering that the OCI model is strongly normative, in a way socially accepted behaviors are mainly concentrated within the "Constructive" culture.

These results are interpreted according to previous research efforts pointing to greater desirability of the "Constructive" cluster over the "Defensive" clusters within the organizational culture. Balthazard et al. [11] consider that "Constructive" behaviors should produce desirable outcomes and minimize unwanted results. Within the nuclear industry, "Constructive" styles are linked to effective problem-solving [65]. Previous studies have also highlighted the strong link between "Constructive" culture and safety-relevant aspects, such as a blame-free environment [66], job satisfaction and motivation and satisfaction [67], as well as trust in supervisors and organizations [68]. Other research projects reveal that "Constructive" cultural styles are the most influential to obtain an adequate safety culture [19]. On the contrary, "Defensive" styles seem to be related to detrimental organizational aspects, such as social loafing, stress, low motivation and low job satisfaction [69]. Some "Defensive" behavioral norms (e.g., "Avoidance") are also negatively associated to safety culture [70].

In the light of these findings, one has to wonder to which extent this cultural duality of the "Constructive" and "Defensive" styles is caused by the technological specificity of the nuclear industry. In other words, could the stringent requirements and needs of the nuclear technology be conditioning the coexistence of "Defensive" behaviors and "Constructive" behaviors? Similarly, safety implications should also be considered: to which extent does the safety of nuclear organizations depend on these "Defensive" traits-which clearly foster compliance with the organizational status quo-interweaving within the set of prevailing "Constructive" style norms? Is it possible to enhance safety culture by minimizing "Defensive" behaviors?

To address all these questions, specific investigations should be carried out to determine the impact of some "Defensive" styles on safety, especially in terms of the "Conventional", "Dependent" and "Perfectionistic" norms.

In addition, we consider that it would also be of interest in future research to study how some aspects of the context, such as catastrophic events (e.g., Fukushima), impact on organizational culture. This study, due to its scope and the nature of its data (different companies whose evaluations have been carried out in different time periods), has not allowed this analysis.

\subsection{Existence of Organizational Subcultures within the Spanish Nuclear Industry}

As for the organizational type, results show that there are two clearly differentiated organizational cultures within the Spanish nuclear industry. On the one hand, a group of private companies in charge of commercial nuclear power plants and, on the other hand, auxiliary public organizations 
which support the nuclear industry by conducting activities such as radwaste management and decommissioning, as well as nuclear component and fuel manufacture. This means that compared to auxiliary organizations, nuclear power plants have a more distinct "Constructive" style and put less emphasis on "Passive/Defensive" norms. Furthermore, within the group of nuclear power plants, there are very few differences in the "Constructive" styles and small differentiating nuances in the "Defensive" styles, whereas the group comprised of public nuclear companies perceive culture more heterogeneous, especially in the "Constructive" styles.

It is important to point out that two potentially determining factors of this cultural differentiation could be the type of organizational ownership (private vs. public) and a potentially different concept of risk (power stations focus more on nuclear safety and public companies on conventional risks). Previous studies have proven the differing nature of challenges faced by these two types of organizations within Spain's energy framework [71].

The workplace-based analysis also reveals some differences between individuals working in the facilities versus those in headquarters. Facilities score higher than headquarters in the "Constructive" cluster within the Spanish nuclear industry. Furthermore, facility personnel also score higher in the OCI scales defining the "Defensive" culture. In this regard, it is possible to speak about a facility personnel subculture and a headquarters personnel subculture, both perhaps linked to the level of proximity to technological aspects. In this sense, previous studies highlighted how proximity to technological risks influences the perceptions of individuals [72].

In terms of contractual relationship, analyses suggest there is strong cultural uniformity between own staff and contractors, with both groups of individuals perceiving the organization's cultural norms under the same order of magnitude. Despite being two clearly differentiated groups in the everyday working life (e.g., wages, labor conditions, organizational ownership, etc.), these results may show the strong inclusive nature of plant culture. In other words, the organizational culture has an inclusive property capable of homogenizing all employees, both own staff and contractors, and making them have a similar perception of cultural norms. Culture assessments have included long term-contractors, so the time variable could also be a determining factor in this homogeneous vision. Future studies considering seniority in the organization could analyze this aspect more in depth.

As for Mintzberg's organizational components [47], it seems that labor division and task coordination, which are considered elements structuring organizations, could also be determining factors of the organizational culture (or ideology, as presented by Mintzberg). Thus, results show that the technostructure and operating core have different "Defensive" styles—operating core personnel, who carry out tasks relating to the distinctive activity of the organization (safe and reliable operation and maintenance of the facilities), perceive a more "Passive" and "Aggressive" culture than technostructure personnel, who are more specialized and carry out tasks of less hierarchical nature and involving a larger intellectual challenge. In behavioral terms, operating core personnel seem to perceive organizational norms that promote agreements, encourage a blame-free environment and prevent conflicts, as well as a high level of attention to detail, whereas the technostructure seems to require cultural styles that are more humanistic, with less avoidance and competition among its members. In other words, aspects circumscribed to compliance with standardized activities seem to be more relevant in the operating core than in the technostructure. That would fit the adequacy of the machine bureaucracy model for nuclear power plants, as identified by Mintzberg [47] (p. 315).

In short, the results show that the organizational culture of the Spanish nuclear sector is homogeneous. However, it is also observed that some demographic variables such as organizational type, location and organizational components are associated with differentiated cultural features (subcultures). It is worth asking to what extent this is clear cultural differentiation or, whether it is simply cultural nuances within the framework of a shared general culture. In other words, integration, or differentiation? [23]. Coinciding with the point of view of Trice and Beyer [21], results seem to indicate that the Spanish nuclear sector has a common organizational culture that coexists with some subcultures with which it shares characteristics. 
The potential existence of subcultures within the nuclear industry could have safety implications. These subcultures, as explained in the introductory theoretical framework, are not necessarily a negative factor and could actually increase the organization's adaptive capacity [40-42]. Thus, it is paramount to consider the implications of this cultural differentiation in terms of safety. That would entail, for example, the need to determine how different professional groups address the importance of safety [30]; how these differences are addressed by managers and; to which degree cultural differences can exist without affecting organizational cohesion. These questions highlight the importance of carrying out additional investigations to understand how interactions between culturally differentiated components and groups determine the safety level of high-risk organizations.

\subsection{Limitations}

The lack of information on organizational seniority as well as on the workers department is a limitation for this study, especially since it is a factor that potentially influences the organizational culture $[30,33]$. Another limitation is the fact that we only had information on the organizational components proposed by Mintzberg for one nuclear company. In this regard, the small sample size of some organizational components (e.g., strategic apex) could have limited the statistical significance and power of the analyses. That means results should be interpreted as a reflection of differences between groups with the most extreme scores.

Additionally, it would have been desirable to have responses to open-ended questions to analyze from a qualitative perspective how subcultural differences influence interpretations and employees' courses of action.

\section{Conclusions}

The results of the present study show that the organizational culture of the Spanish nuclear industry is, in terms of Organizational Culture Inventory ${ }^{\circledR}(\mathrm{OCI})$, mainly "Constructive", with some key "Defensive" traits. It is a culture in which a main driving cultural force promoting "Constructive" and collaborative behaviors coexists with other key normative patterns fostering "Defensive" behaviors of the "Conventional", "Dependent" and "Perfectionistic" styles.

Results also show that there are indications of different organizational subcultures. Three factors seem to contribute to its establishment: a) the type of organization (nuclear power plant or auxiliary companies specializing in radwaste management, fuel manufacturing, as well as production of large nuclear components); b) the common workplace (facility or headquarters) and c) aspects deriving from the organizational structure (Mintzberg's organizational components). In terms of type, nuclear power plants are more homogeneous, more "Constructive" and less "Passive/Defensive" than auxiliary nuclear companies. As for the workplace, organizational culture at the facilities seems to be more "Constructive" than at the headquarters. Lastly, if Mintzberg's organizational components are considered, the operating core perceives the organizational culture in more "Defensive" terms than the technostructure. It is worth noting that results show a lack of subcultures associated to contractual relationship types, with homogeneous results between own staff and contractors.

Future research should be conducted to learn more about the complementarity of organizational subcultures as a tool to prevent the existence of 'blind safety spots' [40]. Cultural differences should be considered key factors of safe evolutions in nuclear facilities, meaning research should also focus on how safety is built as a result of cultural interactions [42].

Author Contributions: Conceptualization: E.B., J.N. and J.-M.L.; methodology: E.B., J.N. and J.-M.L.; formal analysis: E.B., J.N. and J.-M.L.; data collection: E.B. and J.N.; writing-original draft preparation: E.B.; visualization: E.B.; supervision: J.N. and J.-M.L.; project administration: J.N. and J.-M.L. All authors have read and agreed to the published version of the manuscript.

Funding: This research was partially funded by the Grant PGC2018-100675-B-I00 from the Spanish Ministry of Science, Innovation and Universities. The APC was funded by CIEMAT. 
Acknowledgments: We thank Sonja B. Haber for providing the assessment team with her magistery and fruitful observations in organizational culture; Human Synergistics for their helpful suggestions about OCI; Jose Delgado for his support in linguistic revision and the Spanish nuclear industry for their independent evaluations in order to improve safety culture.

Conflicts of Interest: The authors declare no conflict of interest. The funders had no role in the design of the study; in the collection, analyses, or interpretation of data; in the writing of the manuscript, or in the decision to publish the results.

\section{References}

1. Cooper, C.L.; Cartwright, S.; Earley, P.C.E. The International Handbook of Organizational Culture and Climate; John Wiley \& Sons: New York, NY, USA, 2001.

2. Malinowski, B. Una Teoría Científica de la Cultura; Grandes Pensadores; Sarpe: Barcelona, Spain, 1984.

3. Rocher, G. Introducción a la Sociología General; Herder: Barcelona, Spain, 1996.

4. Schein, E.H. La Cultura Empresarial y el Liderazgo; Editorial Plaza \& Janes: Barcelona, Spain, 1988.

5. Spencer-Oatey, H. Culturally Speaking: Managing Rapport Through Talk Across Cultures; Open linguistics series; Continuum: London, UK, 2000.

6. Bang, H. Organisasjonskultur (3.utgave) [Organizational Culture]; Tano AS: Oslo, Norway, 1995.

7. Deal, T.E.; Kennedy, A.A. Corporate Cultures: The Rites and Rituals of Corporate Life; Addison-Wesley Pub. Co: Boston, MA, USA, 1982.

8. Martin, J. Organizational Culture: Mapping the Terrain; Sage Publications: Thousand Oaks, CA, USA, 2002.

9. Cooper, M.D. Towards a model of safety culture. Saf. Sci. 2000, 36, 111-136. [CrossRef]

10. Hofstede, G.J. Cultures and Organizations: Software of the Mind: Intercultural Cooperation and Its Importance for Survival; Successful strategist series; McGraw-Hill: New York, NY, USA, 2004.

11. Balthazard, P.A.; Cooke, R.A.; Potter, R.E. Dysfunctional culture, dysfunctional organization. J. Manag. Psychol. 2006, 21, 709-732. [CrossRef]

12. Schein, E.H. Three Cultures of Management: The Key to Organizational Learning. Sloan Manage. Rev. 1996, 38, 9-20.

13. Shortell, S.M.; Jones, R.H.; Rademaker, A.W.; Gillies, R.R.; Dranove, D.S.; Hughes, E.F.X.; Budetti, P.P.; Reynolds, K.S.E.; Huang, C.-F. Assessing the Impact of Total Quality Management and Organizational Culture on Multiple Outcomes of Care for Coronary Artery Bypass Graft Surgery Patients. Med. Care 2000, 38, 207-217. [CrossRef] [PubMed]

14. Eisenberg, E.; Riley, P. Organizational Culture. In The New Handbook of Organizational Communication; Fredric M. Jablin, L.L.P., Ed.; Sage Publications: Thousand Oaks, CA, USA, 2001; pp. 291-322.

15. Niemietz, H.; Kinderen, S.; Constantinidis, C. Understanding the role of subcultures in the enterprise architecture process. In Proceedings of the ECIS 2013 - Proceedings of the 21st European Conference on Information Systems, Utrecht, The Netherlands, 5-8 June 2013; p. 2013.

16. International Atomic Energy Agency. Safety Culture, Safety Series No. 75-INSAG-4; IAEA: Vienna, Austria, 1991.

17. International Atomic Energy Agency Report on Human and Organizational Factors in Nuclear Safety in the Light of the Accident at the Fukushima Daiichi Nuclear Power Plant; IAEA: Vienna, Austria, 2014.

18. Antonsen, S. Safety culture and the issue of power. Saf. Sci. 2009, 47, 183-191. [CrossRef]

19. Mariscal, M.A.; Herrero, S.G.; Toca Otero, A. Assessing safety culture in the Spanish nuclear industry through the use of working groups. Saf. Sci. 2012, 50, 1237-1246. [CrossRef]

20. Schein, E.H. Organizational Culture and Leadership; The Jossey-Bass Business \& Management Series; John Wiley \& Sons: San Francisco, CA, USA, 2010.

21. Trice, H.M.; Beyer, J.M. The Cultures of Work Organizations; Prentice Hall: Englewood Cliffs, NJ, USA, 1993.

22. Reason, J. Achieving a safe culture: Theory and practice. Work Stress 1998, 12, 293-306. [CrossRef]

23. Martin, J. Cultures in Organizations: Three Perspectives; Cultures in Organizations: Three Perspectives; Oxford University Press: New York, NY, USA, 1992.

24. Mearns, K.; Flin, R.; Gordon, R.; Fleming, M. Measuring safety climate on offshore installations. Work Stress 1998, 12, 238-254. [CrossRef]

25. Mumford, M.D.; Vessey, W.B.; Barrett, J.D. Commentary: Measuring divergent thinking: Is there really one solution to the problem? Psychol. Aesthetics, Creat. Arts 2008, 2, 86-88. [CrossRef] 
26. Jermier, J.M.; Slocum, J.W.; Fry, L.W.; Gaines, J. Organizational Subcultures in a Soft Bureaucracy: Resistance Behind the Myth and Facade of an Official Culture. Organ. Sci. 1991, 2, 170-194. [CrossRef]

27. Day, R.D. Leading and Managing People in the Dynamic Organization; Psychology Press: New York, NY, USA, 2014.

28. Helmreich, R.L.; Merritt, A.C. Culture at Work in Aviation and Medicine: National, Organizational and Professional Influences; Routledge Revivals; Taylor \& Francis: London, UK, 2019.

29. Parker, M. Organizational Culture and Identity: Unity and Division at Work; Sage Publications: London, UK, 2000.

30. Rollenhagen, C.; Westerlund, J.; Näswall, K. Professional subcultures in nuclear power plants. Saf. Sci. 2013, 59, 78-85. [CrossRef]

31. Johnson, S.D.; Koh, H.C.; Killough, L.N. Organizational and Occupational Culture and the Perception of Managerial Accounting Terms: An Exploratory Study Using Perceptual Mapping Techniques. Contemp. Manag. Res. 2009, 5. [CrossRef]

32. Koene, B.; Boone, C.; Soeters, J. Organizational factors influencing homogeneity and heterogeneity of organizational cultures. In Cultural Complexity in Organizations: Inherent Contrasts and Contradictions; Sackman, S., Ed.; Sage Publications series; Sage Publications: Thousand Oaks, CA, USA, 1997; pp. 273-293.

33. Black, R.J. Organisational Culture: Creating the Influence Needed for Strategic Success; Universal Publishers: Irvine, CA, USA, 2003.

34. Copuš, L.; Šajgalíková, H.; Wojčák, E. Organizational Culture and its Motivational Potential in Manufacturing Industry: Subculture Perspective. Procedia Manuf. 2019, 32, 360-367. [CrossRef]

35. Mallidou, A.A.; Cummings, G.G.; Estabrooks, C.A.; Giovannetti, P.B. Nurse specialty subcultures and patient outcomes in acute care hospitals: A multiple-group structural equation modeling. Int. J. Nurs. Stud. 2011, 48, 81-93. [CrossRef]

36. Rose, R.A. Organizations as Multiple Cultures: A Rules Theory Analysis. Hum. Relations 1988, 41, 139-170. [CrossRef]

37. Park, J.; Jung, W. Comparing cultural profiles of MCR operators with those of non-MCR operators working in domestic Nuclear Power Plants. Reliab. Eng. Syst. Saf. 2015, 133, 146-156. [CrossRef]

38. International Atomic Energy Agency Safety Culture in Nuclear Installations: Guidance for Use in the Enhancement of Safety Culture, IAEA-TECDOC-1329; IAEA: Vienna, Austria, 2002.

39. Turner, B.A. Man-made Disasters; Wykeham Science Series; Wykeham Publications: London, UK, 1978.

40. Turner, B.A.; Pidgeon, N.F. Man-made Disasters, 2nd ed.; Butterworth-Heinemann: London, UK, 1997.

41. Boisnier, A.; Chatman, J. The Role of Subcultures in Agile Organizations; Division of Research, Harvard Business School: Boston, MA, USA, 2002.

42. Wahlström, B. Finnish and Swedish practices in nuclear safety. Nucl. Saf. a Hum. Factors Perspect. 1999, 49-60.

43. Lofquist, E.A.; Dyson, P.K.; Trønnes, S.N. Mind the gap: A qualitative approach to assessing why different sub-cultures within high-risk industries interpret safety rule gaps in different ways. Saf. Sci. 2017, 92, 241-256. [CrossRef]

44. Mintzberg, H. Structure in Fives: Designing Effective Organizations; Prentice Hall: Englewood Cliffs, NJ, USA, 1983.

45. Mintzberg, H. Mintzberg on Management: Inside Our Strange World of Organizations; Free Press: New York, NY, USA, 1989.

46. Haber, S.B.; O’Brien, J.N.; Ryan, T.G. Model development for the determination of the influence of management on plant risk. In Proceedings of the International Conference on Human Factors and Power Plants, Monterey, CA, USA, 5 June 1988; IEEE: Monterey, CA, USA, 1988; pp. 349-352.

47. Mintzberg, H. The Structuring of Organizations: A Synthesis of the Research; Theory of Management Policy Series; Prentice Hall: Englewood Cliffs, NJ, USA, 1979.

48. Guldenmund, F.W. Understanding Safety Culture Through Models and Metaphors. In Safety Cultures, Safety Models; Gilbert, C., Journé, B., Laroche, H., Bieder, C., Gilbert, C., Journé, B., Laroche, H., Bieder, C., Eds.; Springer International Publishing: Cham, Switzerland, 2018; pp. 21-34.

49. Van Maanen, J.; Barley, S. Cultural organization: Fragments of a theory. In Organizational Culture; Frost, P., Moore, L., Louis, M.R., Lundberg, C., Martin, J., Eds.; Sage Publications: Beverly Hills, CA, USA, 1985; pp. 31-53.

50. Haber, S.B.; Shurberg, D.A.; Barriere, M.T.; Hall, R.E. The Nuclear Organization and Management Analysis Concept methodology: Four years later. In Proceedings of the Conference Record for 1992 5th Conference on Human Factors and Power Plants, HFPP, Monterey, CA, USA, 7-11 June 1992; 1992; pp. 389-393. 
51. Cooke, R.A.; Lafferty, J.C. Organizational Culture Inventory; Human Synergistics: Plymouth, MO, USA, 1987.

52. Scott, T.; Mannion, R.; Davies, H.; Marshall, M. The quantitative measurement of organizational culture in health care: A review of the available instruments. Health Serv. Res. 2003, 38, 923-945. [CrossRef]

53. Cooke, R.A.; Szumal, J.L. Measuring Normative Beliefs and Shared Behavioral Expectations in Organizations: The Reliability and Validity of the Organizational Culture Inventory. Psychol. Rep. 1993, 72, 1299-1330. [CrossRef]

54. Seago, J.A. Registered nurses, unlicensed assistive personnel, and organizational culture in hospitals. J. Nurs. Adm. 2000, 30, 278-286. [CrossRef]

55. Xenikou, A.; Furnham, A. A Correlational and Factor Analytic Study of Four Questionnaire Measures of Organizational Culture. Hum. Relations 1996, 49, 349-371. [CrossRef]

56. Bellot, J. Defining and Assessing Organizational Culture. Nurs. Forum 2011, 46, 29-37. [CrossRef] [PubMed]

57. Cooke, R.A. OCI: Organizational Culture Inventory: Leader's Guide; Human Synergistics: Plymouth, MO, USA, 1989.

58. Szumal, J.L. Organizational Culture Inventory: Interpretation and Development Guide; Human Synergistics: Plymouth, MO, USA, 1998.

59. IBM Corp. IBM SPSS Statistics for Windows; Version 22.0; IBM Corp: Armonk, NY, USA, 2013.

60. Cronbach, L.J. Coefficient alpha and the internal structure of tests. Psychometrika 1951, 16, 297-334. [CrossRef]

61. Nunnally, J.C.; Bernstein, I.H. Psychometric Theory; McGraw-Hill series in psychology; McGraw-Hill: New York, NY, USA, 1994.

62. Anderson, J.C. An Approach for Confirmatory Measurement and Structural Equation Modeling of Organizational Properties. Manage. Sci. 1987, 33, 525-541. [CrossRef]

63. Cohen, J. Statistical Power Analysis for the Behavioral Sciences, 2nd ed.; Lawrence Erlbaum Associates: Hillsdale, MI, USA, 1988.

64. Cooke, R.A.; Rousseau, D.M. Behavioral Norms and Expectations: A quantitative approach to the assessment of organizational culture. Gr. Organ. Manag. 1988, 13, 245-273. [CrossRef]

65. Shurberg, D.A.; Haber, S.B. An Organizational Survey of the Strategic Petroleum Reserve; Brookhaven National Laboratory: Upton, NY, USA, 1992.

66. Silla, I.; Navajas, J.; Koves, G.K. Organizational culture and a safety-conscious work environment: The mediating role of employee communication satisfaction. J. Safety Res. 2017, 61, 121-127. [CrossRef]

67. Rousseau, D. Assessing organizational culture: The case for multiple methods. In Organizational Climate and Culture; Schneider, S., Ed.; Jossey-Bass: San Francisco, CA, USA, 1990; pp. 153-192.

68. Weidner, C.K. Trust and Distrust at Work: Normative and Dyad-exchange Influences on Individual and Subunit Performance. Ph.D. Thesis, University of Illinois at Chicago, Chicago, IL, USA, 1997.

69. Cooke, R.A.; Szumal, J.L. Using the organizational culture inventory to understand operating cultures of organizations. Handb. Organ. Cult. Clim. 2000, 54, 147-162. [CrossRef]

70. García-Herrero, S.; Mariscal, M.A.; Gutiérrez, J.M.; Toca-Otero, A. Bayesian network analysis of safety culture and organizational culture in a nuclear power plant. Saf. Sci. 2013, 53, 82-95. [CrossRef]

71. Germán, S.; Navajas, J.; Silla, I. Safety challenges in Spain's nuclear industry according to sector experts. Prog. Nucl. Energy 2016, 90, 155-163. [CrossRef]

72. Arias, J.P.; Bronfman, N.C.; Cisternas, P.C.; Repetto, P.B. Hazard proximity and risk perception of tsunamis in coastal cities: Are people able to identify their risk? PLoS ONE 2017, 12, e0186455. [CrossRef] [PubMed] 